Chapter 12

\title{
Amyloid Nephropathy: A Practical Diagnostic Approach and Review on Pathogenesis
}

\author{
Paisit Paueksakon \\ Additional information is available at the end of the chapter \\ http://dx.doi.org/10.5772/64083
}

\begin{abstract}
Amyloidosis comprises a group of protein-folding disorders in which extracellular deposits share unique Congo red staining properties and fibrillary ultrastructural appearance. These fibrillary deposits ultimately cause tissue destruction and progressive disease. Amyloidosis can be either systemic affecting multiple organs or localized. Renal involvement by amyloidosis (amyloid nephropathy) is a frequent manifestation of systemic amyloidosis. Immunofluorescence, immunohistochemistry (IHC), and more recently laser microdissection and mass spectrometry (LMD/MS) are important techniques in typing of amyloid nephropathy. This in-depth review discusses practical diagnostic approach and pathogenesis of amyloid nephropathy and includes discussion of treatment and prognosis.
\end{abstract}

Keywords: amyloid nephropathy, light microscopy, immunofluorescence, immunohistochemistry, electron microscopy, proteomics

\section{Introduction}

Amyloidosis comprises a group of protein-folding disorders in which extracellular deposits share unique Congo red staining properties and fibrillary ultrastructural appearance [1]. These fibrillary deposits ultimately cause tissue destruction and progressive disease. Amyloid consists of randomly arranged, nonbranching fibrils that measure 8-12 $\mathrm{nm}$ in diameter [1]. Amyloidosis is a rare group of diseases, with an estimated prevalence of 1: 60,000 [2]. In the USA and Europe, amyloidosis derived from immunoglobulin (Ig) light chain (AL) secondary to plasma cell dyscrasia is the most prevalent form, followed by reactive AA amyloido- 
sis (AA) derived from serum amyloid A (SAA), which is typically associated with chronic inflammatory conditions. This is in contrast to developing countries in Africa and Middle East of Asia, where AA is much more common than AL [3-5]. Leukocyte chemotactic factor 2 amyloidosis (ALECT2), derived from leukocyte chemotactic factor 2 protein (LECT2), is newly recognized as a common type of amyloid, with unknown etiology [6]. Familial amyloidosis is diagnosed with increasing frequency with the use of new immunohistochemical studies and mass spectrometry [7]. Amyloidosis can be either systemic affecting multiple organs or localized. Renal disease is a frequent manifestation of systemic amyloidosis with AL, previously called primary amyloidosis, the most common type involving the kidney.

\section{Amyloid nephropathy}

The types of amyloid are categorized by the chemical composition of the proteins. There are more than 25 precursor proteins identified as major proteins in amyloid deposition so far. A large study from the Mayo clinic [8] showed that among 474 patients with amyloid diagnosed by renal biopsies between 2007 and 2011, Ig-related amyloidosis (AIg) was the most common form involving the kidney (85.9\%), followed by AA (7.0\%), ALECT2 (2.7\%), fibrinogen A $\alpha$ chain amyloidosis (AFib) (1.3\%), apolipoprotein AI amyloidosis (AApo AI), apolipoprotein AII amyloidosis (AApo AII), or apolipoprotein AIV amyloidosis (AApo AIV) (0.6\%), AA/light and heavy chain amyloidosis (AHL) (0.2\%), and unclassified amyloidosis (2.3\%). AIg in most cases is derived from fragments of monoclonal light-chain protein (AL). However, in rare cases, AIg is derived from truncated Ig heavy chain and light chain (AHL) or isolated truncated Ig heavy chain [8,9]. AIg is associated with B-cell lymphoproliferative disorders including multiple myeloma and plasma cell dyscrasia, B-cell lymphoma, and Waldenström's macroglobulinemia [8]. In contrast, AA is characterized by tissue deposition of serum amyloid A protein, which is derived from an acute-phase reactant protein synthesized by the liver [10]. AA is seen in conditions associated with chronic inflammation including rheumatoid arthritis, ankylosing spondylitis, chronic draining infections (i.e., osteomyelitis, chronic skin infections including decubitus ulcers, bronchiectasis, and chronic sinusitis), Crohn disease, tuberculosis, and familial Mediterranean fever (FMF) [10]. Familial amyloidosis comprises another group of amyloid that is now being diagnosed more frequently and includes amyloid derived from transthyretins (TTR) [11], fibrinogen [12], lysozyme (Lys) [13], gelsolin (Gel) [14], Apo AI [15], Apo AII [16], and Apo AIV [17]. ALECT2 nephropathy was first described in 2008 [6, 18]. LECT2 is a chemotactic factor for neutrophils and has other physiologic functions, including cell proliferation, immunomodulation, repair after injury, tumor suppression, and glucose metabolism $[6,18]$. ALECT2 is now the third most common type of amyloid nephropathy in the USA and accounts for $2.5-2.7 \%$ of amyloid nephropathy cases [6, 18]. ALECT2 involves mainly in the kidney and liver but rarely involve other organs such as spleen, adrenal, and myocardium $[6,18]$. Type and precursor protein of amyloid nephropathy are summarized in Table 1. 


\begin{tabular}{ll}
\hline Amyloid precursor protein & Amyloid type \\
\hline Restricted light chain (lambda or kappa) & AL \\
Ig heavy chain & AH \\
Ig heavy and light chain & AHL \\
Serum amyloid associated protein (SAA) & AA \\
Leukocyte chemotactic factor type 2 (LECT2) & ALECT2 \\
Fibrinogen A- $\alpha$ chain & AFib \\
Transthyretin (TTR) & ATTR \\
Apolipoprotein A-I & AApo AI \\
Apolipoprotein A-II & AApo AII \\
Apolipoprotein A-IV & AApo AIV \\
Gelsolin & AGel \\
Lysozyme & ALys \\
\hline
\end{tabular}

Table 1. Type and precursor protein of amyloid nephropathy.

\section{Clinical features}

The clinical features of patients with amyloidosis vary, depending on the varying predilection of different types of amyloid for specific organ involvement. As described above, renal involvement is a frequent manifestation of amyloidosis, more often in AIg nephropathy, AA nephropathy, and some forms of familial amyloidosis [10, 12]. Amyloid nephropathy of any type is more common in men than in women [8]. A large retrospective review of patients with amyloidosis evaluated from 1981 to 1992 at the Mayo Clinic in Rochester, Minnesota, revealed 1315 patients, including 918 patients with AL amyloidosis (69.8\%). Of these, 474 patients had new-onset AL amyloidosis, including $69 \%$ men and 31\% women with median age of 64 years [19]. At the time of diagnosis, about $17 \%$ of AL patients had either multiple myeloma or smoldering myeloma and about $16 \%$ had history of monoclonal gammopathy of undetermined significance (MGUS). On presentation, about $51 \%$ of men and $47 \%$ of women had renal failure, and about $73 \%$ of patients had proteinuria. The median 24 -h urine protein was $1.2 \mathrm{~g} / \mathrm{d}$ and in the patients with full nephrotic syndrome, about a quarter of patients, the mean 24-h urine protein excretion was $7.0 \mathrm{~g} / \mathrm{d}$. Serum protein electrophoresis (SPEP) revealed a monoclonal protein in about $48 \%$ of patients and when serum immunoelectrophoresis was tested the percentage increased to about $72 \%$. A monoclonal light chain was detected in about $73 \%$ of the patients by urine immunoelectrophoresis or immunofixation, including about $68 \%$ with lambda and about $32 \%$ with kappa. Overall, about $89 \%$ of the patients with AL amyloidosis showed a serum or urine monoclonal spike (M spike).

Patients with AA nephropathy usually present at younger age than AL patients, whereas ALECT2 is more common in older patients. ALECT2 nephropathy mainly affects patients of 
Hispanic or Mexican origin and rarely affects Caucasian patients, whereas AL and AA do not show evident ethnic differences [6, 18]. As in AL amyloid, proteinuria is also the most common clinical presentation in AA, ALECT2, and familial amyloid nephropathy [8]. Extrarenal manifestations of amyloidosis include congestive heart failure caused by myocardial infiltration by amyloid, orthostatic hypotension, bladder dysfunction, and dysesthesias caused by amyloid infiltration into autonomic and peripheral nerves, lymphadenopathy, hepatomegaly, splenomegaly, and macroglossia [18, 20]. The treatment and prognosis of amyloid nephropathy will be discussed below.

\section{Molecular mechanisms and pathogenesis of amyloidosis}

Misfolding of extracellular proteins has a prominent role in the molecular mechanisms and pathogenesis of amyloidosis [21, 22]. The misfolded proteins are highly prone to self-aggregation. There are different mechanisms of formation of pathologic misfolded proteins [22]. The first is based on intrinsic propensity of the protein to assume pathologic conformation, which becomes more evident with aging. Examples of these mechanisms are evident when molecularly normal transthyretin misfolds in patients with senile systemic amyloidosis [22]. The second way is due to alteration of the normal protein sequence, as seen with the replacement of a single amino acid in protein, e.g., in AL and familial amyloidosis [22]. Only a small portion of Ig light chains is amyloidogenic; thus, AL nephropathy occurs only in about $12-15 \%$ of the patients with multiple myeloma [23]. The amyloid fibrils in amyloid nephropathy consist of either intact light chains containing the variable and constant domains or solely the variable domains, which contains the N-terminus portion of the light-chain molecule. The V $\lambda \mathrm{VI}$ subgroup of the light chain preferentially leads to amyloid formation in patients with AL nephropathy $[23,24]$. Therefore, it appears that germ line sequences, which enhanced near the $\mathrm{N}$-terminus of the lambda light chain and in the V $\lambda$ VI of the light chain may be prone to mutations that generate amyloidogenic light chains. These altered proteins lead to destabilization of light chain and increase the likelihood of fibril formation [25]. In familial amyloidosis, such as Transthyretin-related hereditary amyloidosis (ATTR) and Lysozyme-related amyloidosis (ALys), the substitution of a single amino acid transforms a normal protein into an amyloidogenic protein [26, 27]. The unstable protein produced by amino acid substitution may allow the protein to precipitate when stimulated by the local physicochemical milieu, such as local surface $\mathrm{pH}$, electric field, and hydration forces on the cellular surfaces [22]. A third mechanism contributing to amyloid formation is proteolytic remodeling of the protein precursor, as seen in Alzheimer's disease, in which the fibrils are composed of proteolytic fragments of 39-43 residues derived from 753-residue $\beta$-amyloid precursor protein (APP) [28]. This type of amyloid does not affect the kidney. In addition, excessive concentration of amyloidogenic protein due to unregulated production of high local concentration can promote amyloidosis [29]. When the protein precursor reaches a critical point of local concentration, it triggers fibril formation. This mechanism is enhanced further by environmental physicochemical factors and interaction with extracellular matrix. This mechanism may occur in AA amyloidosis associated with chronic inflammatory conditions or familial Mediterranean 
fever [30]. The excessive concentration of amyloidogenic protein may also be caused by decrease in clearance from the body; e.g., Beta- 2 microglobulin associated amyloidosis $(\mathrm{A} \beta 2 \mathrm{M})$ develops in end-stage renal disease patients who received long-term dialysis because of ineffective clearance of $\beta 2 \mathrm{M}$ from circulation during dialysis or due to inability of the body to destroy the accumulation by natural mechanism [31]. Regardless of mechanism of misfolding, the misfolded proteins are prone to self-aggregate, generating protofilaments that interact to form fibrils [22].

In AL nephropathy, amyloid formation in the kidney first begins in the mesangium. The specific uptake of light-chain protein by mesangial cells underlies the predominant kidney tropism and is an important step in amyloid fibril formation. There are several factors that might promote or decelerate amyloid deposition in glomeruli, including the negative ion charge and the high concentration of glycosaminoglycan of the glomerular basement membranes with the presence of enzyme proteases that could render protein amyloidogenic [32]. Mesangial cells are modified smooth muscle cells, which have phagocytic activity [33]. Upon interaction with light-chain proteins, the light-chain proteins are avidly internalized and delivered to the primary lysosomes where the amyloid fibrils are primarily formed [34]. During this process, the mesangial cells transform into a macrophage phenotype with prominent primary lysosomes, making them more capable of processing of internalized amyloidogenic light-chain proteins and fibril formation [34]. The amyloid deposition within the mesangium further stimulates metalloproteinase enzymes, causing mesangial matrix degradation, inhibiting transforming growth factor $\beta$ (TGF- $\beta$ ) and thus impairing mesangial matrix repair $[33,35]$ and increasing apoptosis, finally leading to significant mesangiolysis and replacement of the mesangial area by amyloid deposits [36]. These changes result in the absence of mesangial argyrophilia and significant mesangial cell deletion in the advanced stage of glomerular amyloidosis [34].

LECT2 has multiple functions including as a cytokine involved in chemotaxis of neutrophils and a growth factor involved in cell proliferation and regulation of repair after injury, immunomodulation, tumor suppression, and glucose metabolism [37]. The pathogenesis of ALECT2 is not well understood, but may be due to increased synthesis of LECT2 by hepatocytes or secondary to hepatocellular damage or involve interference, possible due to genetic defect, in the LECT2 catabolism or LECT2 transportation, which may give rise to local LECT2 tissue concentration and finally lead to amyloid fibril formation [6, 18, 37].

The normal plasma protein serum amyloid P component (SAP), a glycoprotein that belongs to the pentraxin family, independently binds to fibrils in all types of amyloid and contributes to pathogenesis of amyloidosis [38]. SAP is highly protected against proteolysis, and a binding of SAP to amyloid fibrils in vitro protect them from proteolytic enzymes and degradation by phagocytic cells. Moreover, SAP is a stubborn glycoprotein that can persist within human amyloid deposits for prolonged periods and is completely unmodified with respect to circulating SAP [38]. It is suggested that SAP may contribute to the failure to clear amyloid deposition in vivo, leading to tissue architecture destruction and organ dysfunction.

Furthermore, amyloid can be deposited in multiple organs, and this tendency might depend on several physicochemical factors, such as high concentration of local protein, low $\mathrm{pH}$, 
presence of proteolytic processing, and seeding of protofilaments [22]. The amyloid deposits cause tissue architecture destruction, presumed to cause organ dysfunction [22]. Furthermore, the amyloidogenic precursor proteins, folding intermediates, and protofilaments have toxicities independent of the amyloid deposits and these toxicities can also contribute to disease manifestations [39].

\section{Gross findings}

Postmortem examination of patients with amyloidosis generally shows enlarged kidneys, unlike other causes of chronic kidney disease (CKD) where kidneys are small and shrunken. In addition, cut surfaces of kidney in patients with amyloid nephropathy are pale, firm, waxy, and flat [38] (Figure 1a), which are different from the normal kidney or the kidney in the patients with CKD (Figure 1b), which bulges slightly causing in slight curvature of the cut surfaces.
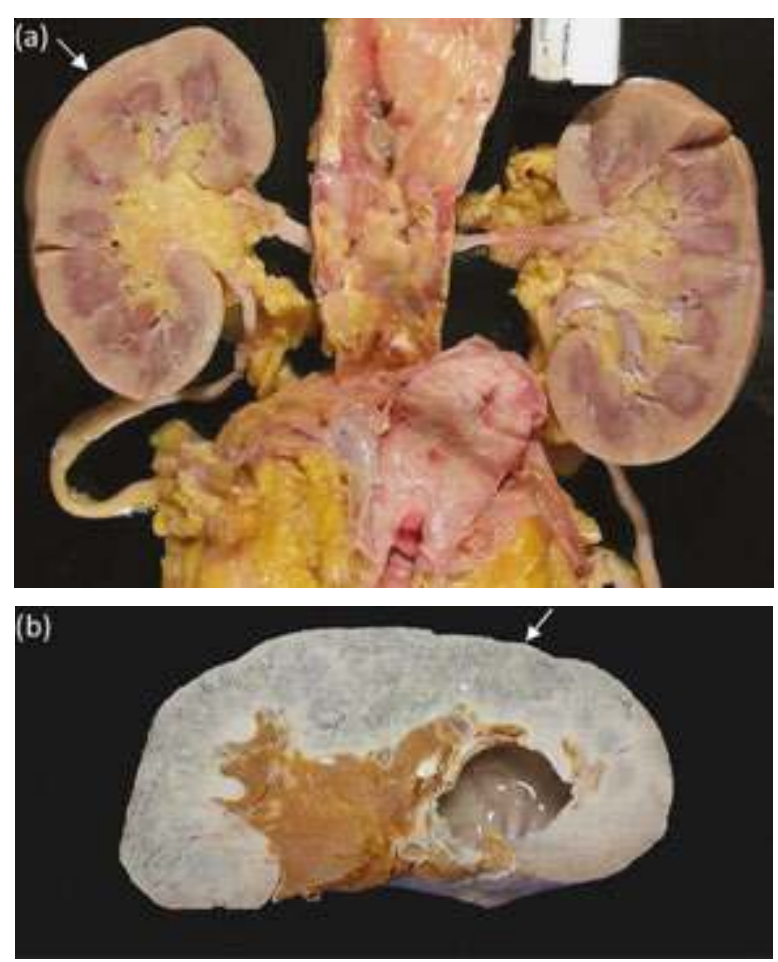

Figure 1. At autopsy of a patient with amyloid nephropathy, the kidney is enlarged and pale with waxy and flat cut surface (a, arrow), which is different from the kidney in a patient with chronic kidney disease with a simple cyst, which bulges slightly (arrow) resulting in slight curvature of the cut surfaces (b). 


\section{Histologic diagnosis and identification of amyloid}

\subsection{Light microscopy}

The light microscopic (LM) findings of amyloidosis are identical regardless of the type of amyloid. Glomerular amyloid deposition begins with progressive accumulation of acellular amorphous eosinophilic material (cotton candy appearance) on hematoxylin and eosin (H\&E)stained sections (Figure 2) that appear pale with the periodic acid Schiff (PAS) stain (Figure $3 \mathbf{a}$ and $\mathbf{b}$ ). In the advanced stage, the mesangial matrix is extensively replaced by acellular amorphous material exhibiting uniform expansion with compression of the capillary spaces and occasional nodular formation, resembling diabetic nephropathy or monoclonal immunoglobulin deposition disease. The nodular pattern is seen more frequently in AA nephropathy. The amyloid deposits are paler on PAS stain than the Kimmelstiel-Wilson nodules in diabetic nephropathy, or deposits in light-chain deposition disease or fibrillary glomerulonephritis. Further, fibrillary glomerulonephritis typically is proliferative, with increased cellularity seen by light microscopy. The amyloid deposits stain weakly or are negative with Jones methenamine silver stain (JMS) and appear as negative defects in the expanded mesangium and thick glomerular basement membranes (Figure $4 \mathbf{a}$ and $\mathbf{b}$ ). Occasionally, there is a focal parallel alignment of amyloid fibrils in the subepithelial zone that results in focal capillary wall spikes, which are best visualized by JMS (Figure 5). These spikes are focal, closely clustered, and longer than the typical spikes of membranous nephropathy. The focal clusters of spikes may resemble feathers, so-called feathery spikes. Amyloid feathery spikes are more common in AL than AA or familial amyloidosis [7]. Rarely crescent formation can be seen in both AA and AL [7], indicating glomerular basement membrane breaks, the injury that triggers crescent formation, can occur. Vascular involvement by amyloidosis is common, frequently involving arteriolar walls, followed by arteries, peritubular capillaries, and veins. In rare cases, particularly in AL or in ATTR nephropathy, the vessels are the only part in the kidney where amyloid is demonstrated. Interstitial amyloid deposition is seen in about $50 \%$ of cases but is present in most cases of ALECT2 nephropathy (Figure 6). Glomerular involvement is not extensive in ALECT2 and apolipoprotein AI (AApo AI/), AII (AApoAII), and AIV (AApoAIV) nephropathy in comparison with other types of amyloid. In addition, the histology of AFib nephropathy is very characteristic, showing glomerular enlargement with near-total replacement of the glomeruli by amyloid, with little or no vascular or interstitial involvement [10]. Special IF and immunohistochemistry (IHC) together with mass spectrometry analyses are typically used to identify the type of amyloid (see below). However, potassium permanganate treatment prior to Congo red staining has been used to distinguish between AA and AL nephropathy: after this treatment, birefringent Congo red staining is lost by AA but retained by AL. This technique is not commonly used and has been replaced by more specific SAA immunohistochemistry (IHC).

Amyloid is defined by its tinctorial characteristics, which include Congo red positivity (orange, salmon pink, or pale rose staining, Figure 7). The Congo red stain gives apple-green or traffic light green birefringence under polarized light (Figure 8). The mesangial expansion can be focal and may be segmental, global, or even nodular. However, the degree of 
proteinuria does not correlate with the amount of amyloid deposition; as a result, cases with early amyloidosis with scant and segmental amyloid deposition can be mistakenly diagnosed as minimal change disease if no Congo red stain, immunofluorescence (IF) and electron microscopy (EM) is performed. To demonstrate small amounts of amyloid deposits in tissue sections, it is recommended that the sections be cut thicker than normal $(6 \mu \mathrm{m}$, instead of customary $2 \mu \mathrm{m}$ ) [40]. Proper detection of apple green birefringence depends on the intensity of the transmitted light and, thus, a strong light source is strongly suggested to maximize results. In early amyloidosis with small amounts of amyloid, it might be difficult to demonstrate Congo red positivity. Therefore, an alternative way of identifying a small amount of amyloid deposits by Congo red stain is to place the stained section under fluorescent light; amyloid then is bright red [41] (Figure 9). Of note, false positivity may result from overstaining, and this technique is not specific for amyloid. Thus, amyloid must be confirmed by apple green polarization, immunofluorescence, IHC, and/or electron microscopy. An alternative option to demonstrate amyloid deposits in cases with no paraffin embedded tissue available is to perform Congo red stain on frozen tissue (Figure 10). This technique is more sensitive than a Congo red stain performed on paraffin embedded tissue from our experience. Of note, positive controls should then, of course, also be performed on frozen tissues.

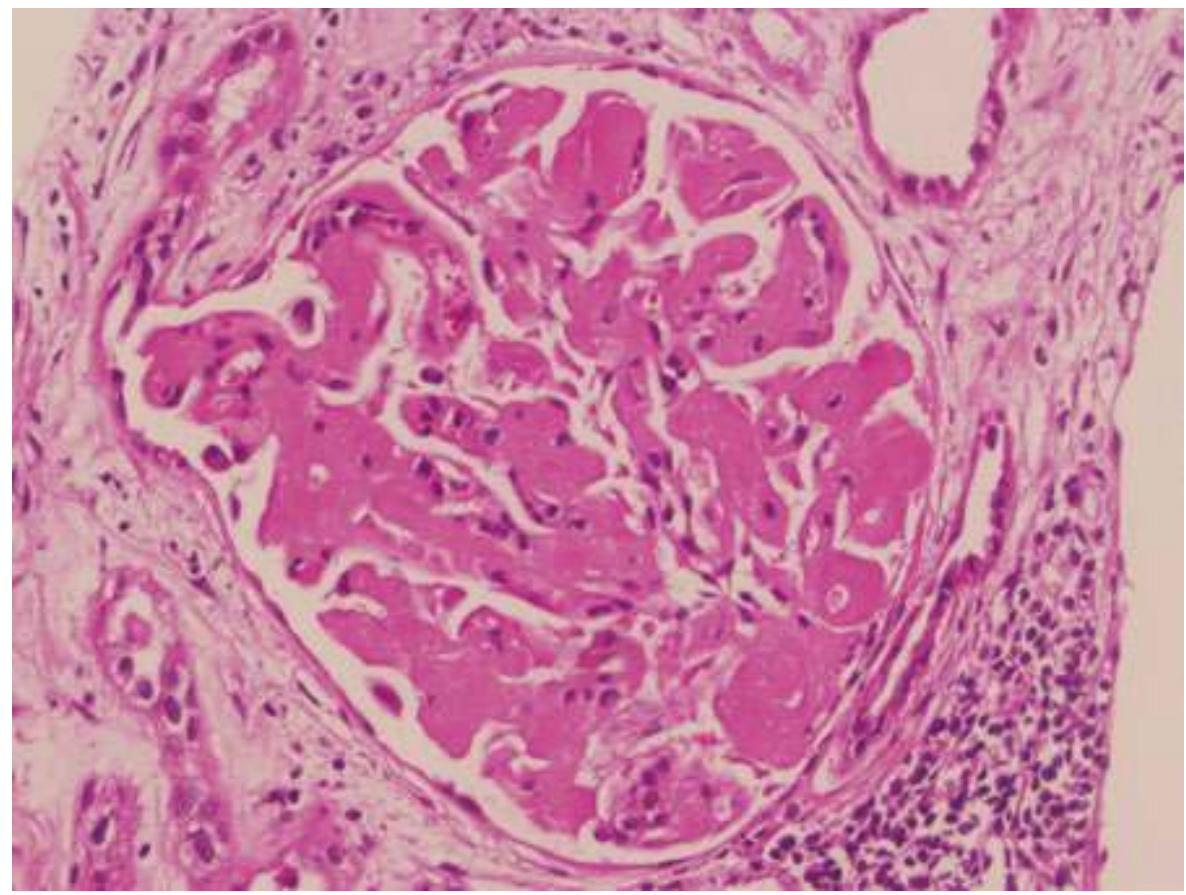

Figure 2. In amyloid nephropathy, there is extensive mesangial expansion by amorphous eosinophilic acellular material ("cotton candy" appearance), which segmentally extends to the glomerular capillary loops (H\&E stain, original magnification $\times 400)$. 

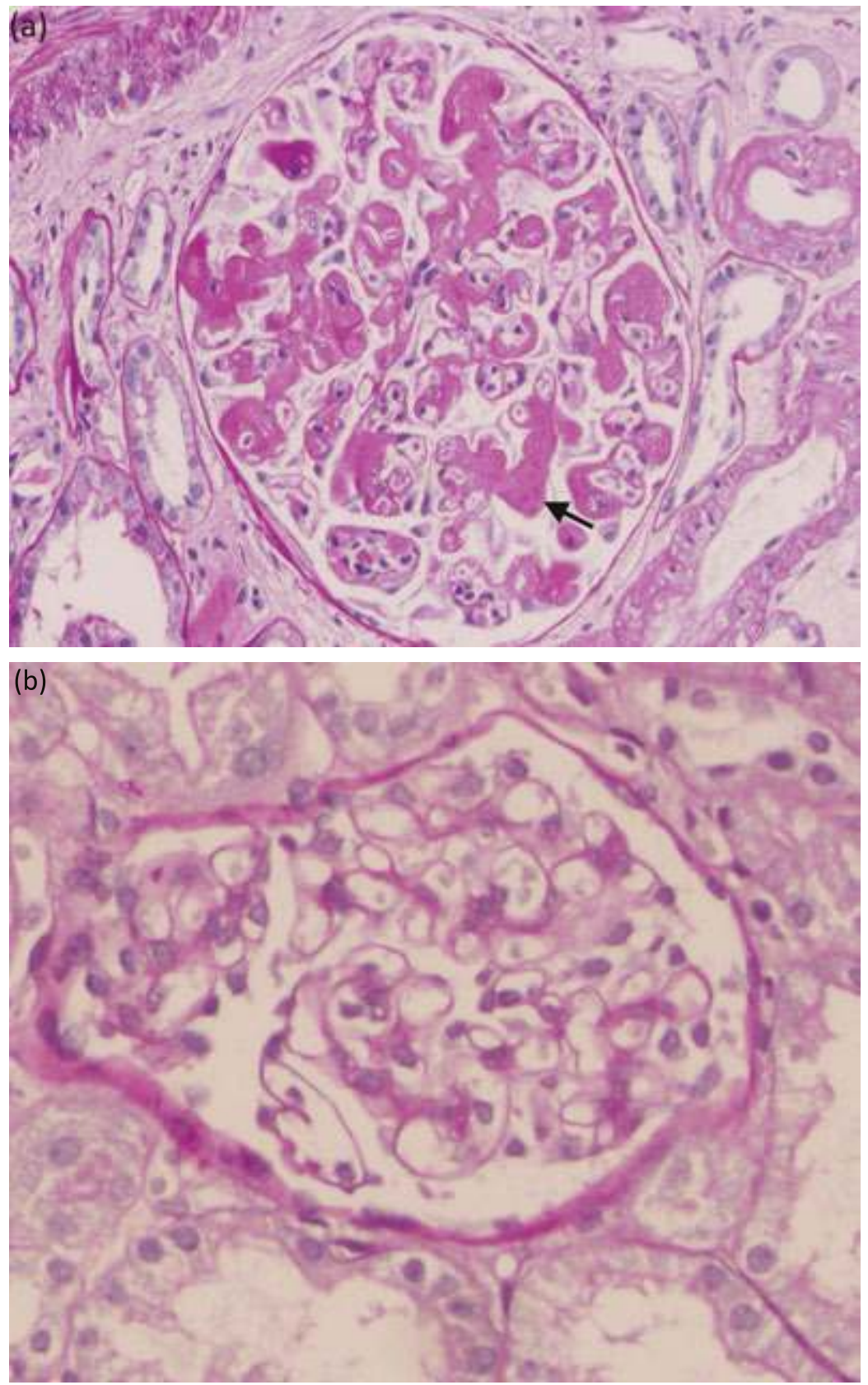

Figure 3. In amyloid nephropathy (a), mesangial areas are globally expanded by weak PAS positive acellular deposits (arrow) in comparison to a glomerulus (b) in normal kidney biopsy (PAS stain, original magnification $\times 400$ ). 

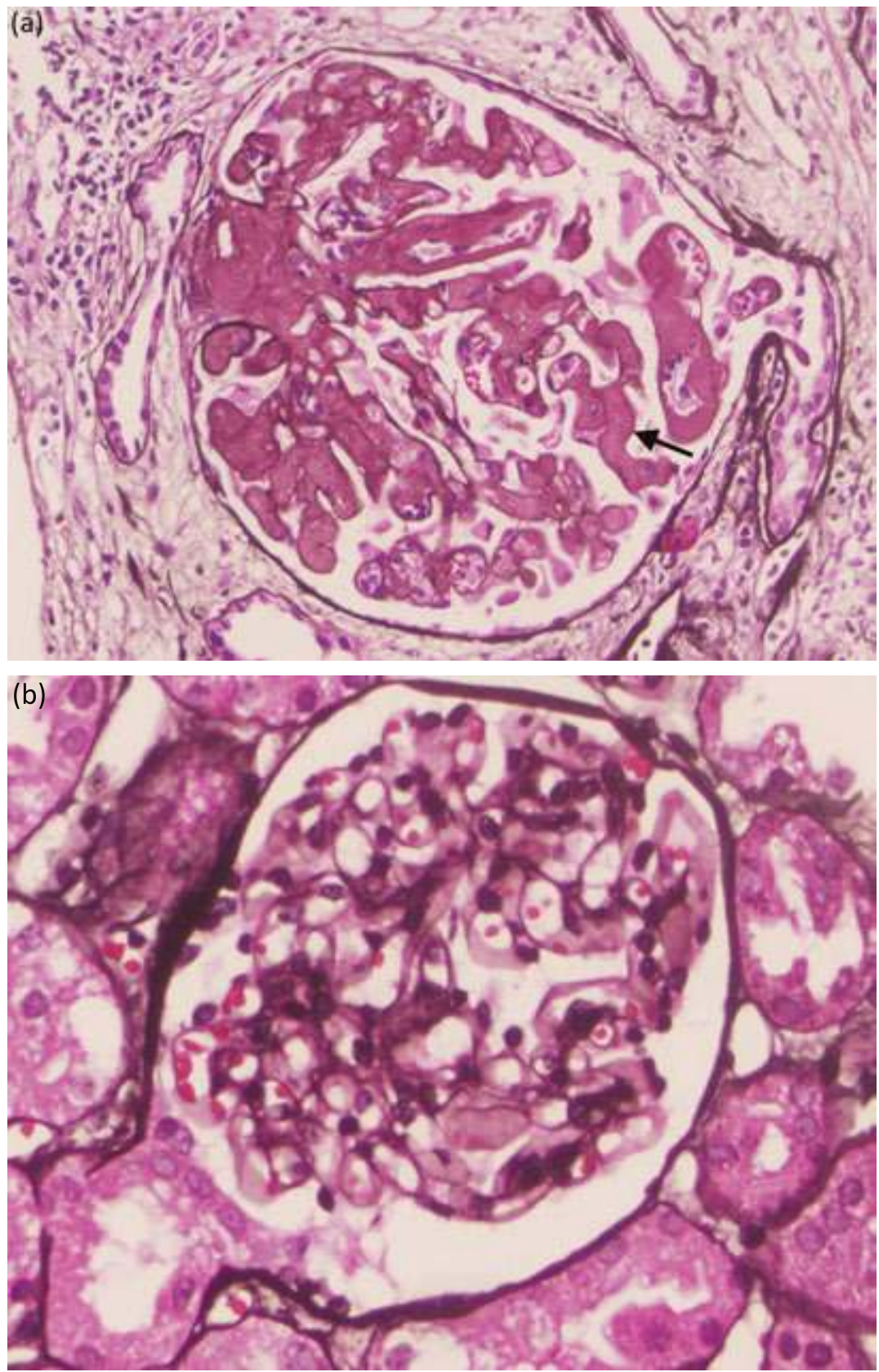

Figure 4. In amyloid nephropathy (a), mesangial amyloid deposits are nonargyrophilic (silver negative, arrow) in comparison with a glomerulus in the normal kidney biopsy (silver positive, b) (JMS stain, original magnification $\times 400$ ). 


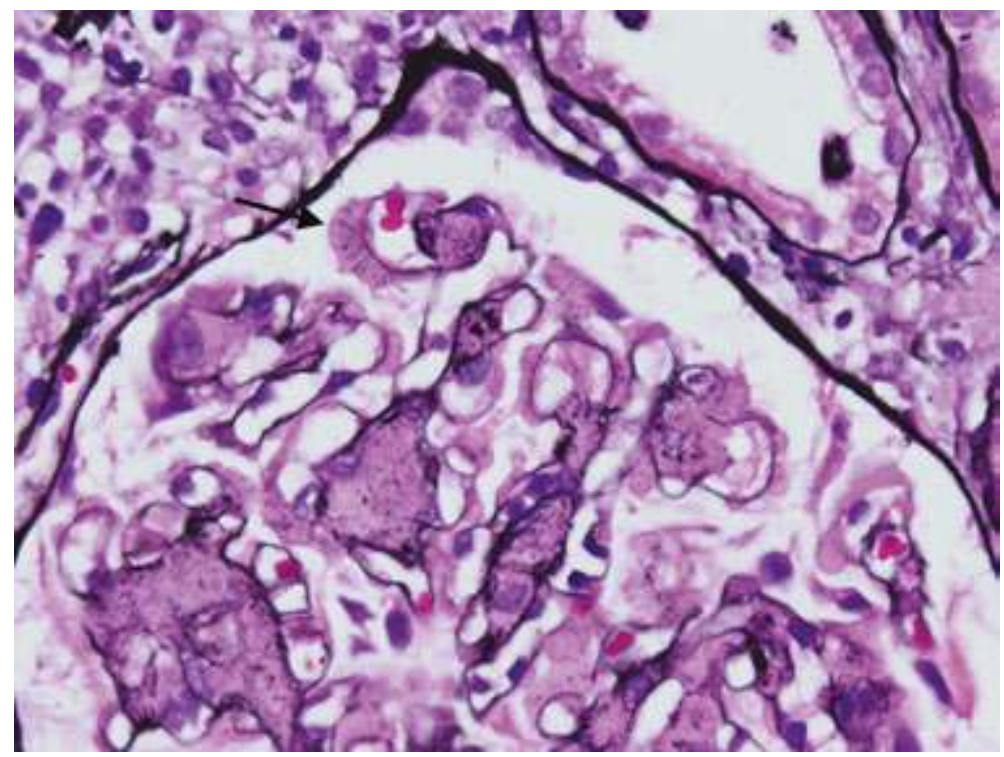

Figure 5. Feathery spikes (arrow) are a characteristic features of amyloid nephropathy seen on JMS, and are seen more frequently in AIg than other forms of amyloid nephropathy (JMS stain, original magnification $\times 400$ ).

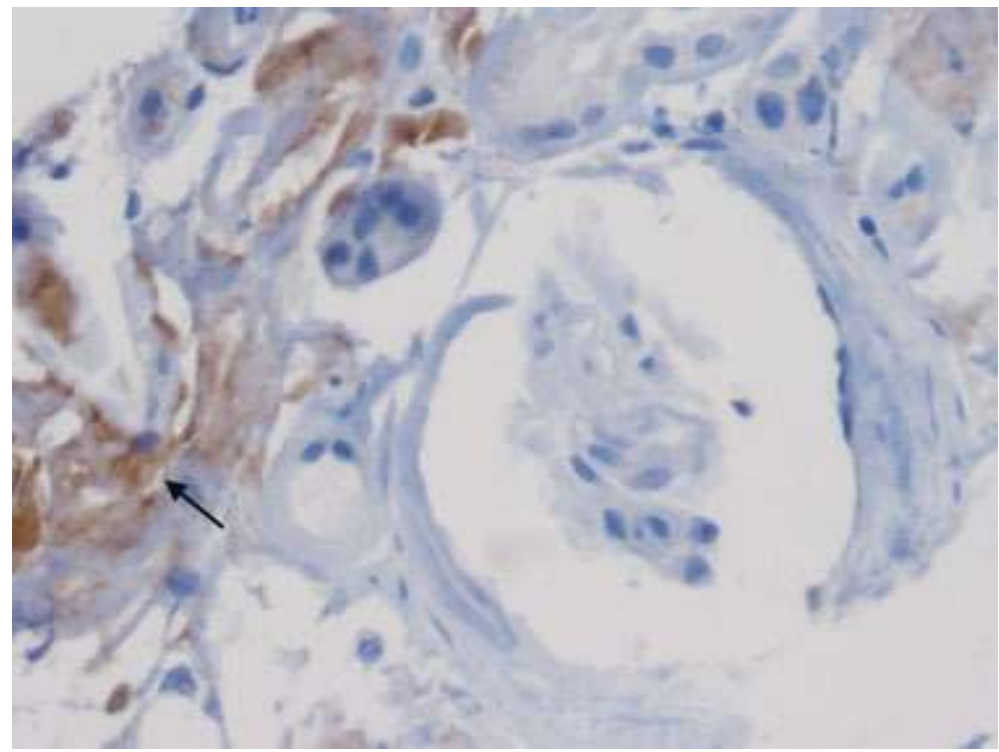

Figure 6. ALECT2 amyloid nephropathy with intense interstitial amyloid (arrow) seen by immunohistochemistry staining (anti-LECT2 IHC, original magnification $\times 400$ ). 


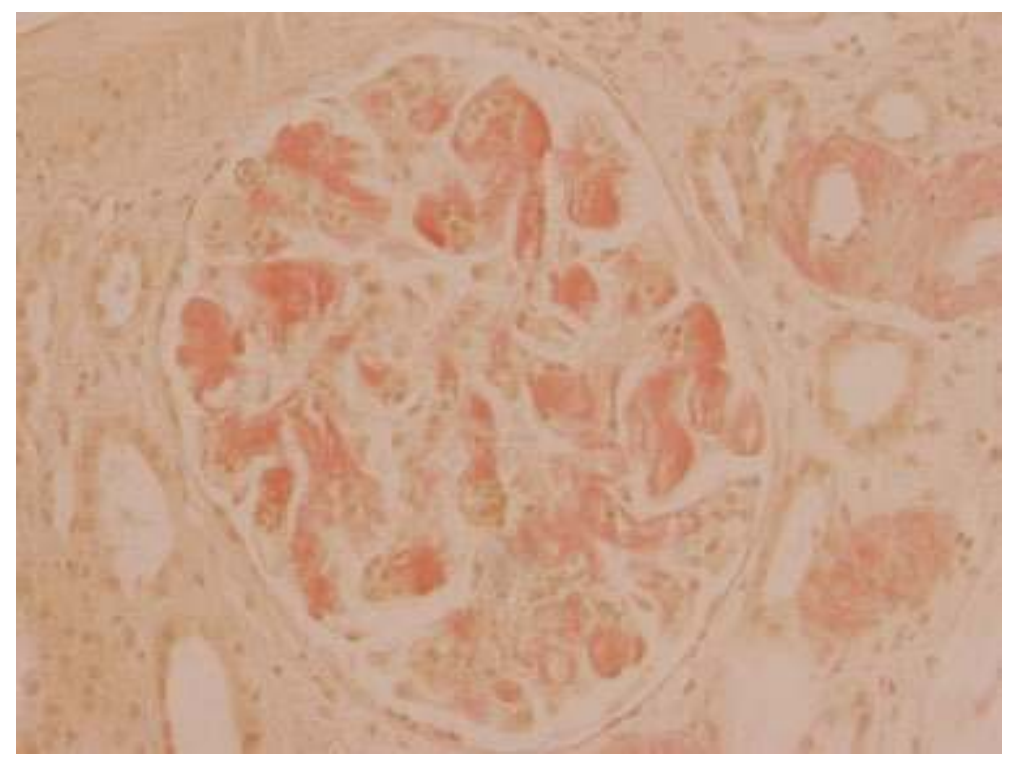

Figure 7. Congo red positive mesangial deposits of amyloid with orange or salmon pink staining (Congo red stain, original magnification $\times 400$ ).

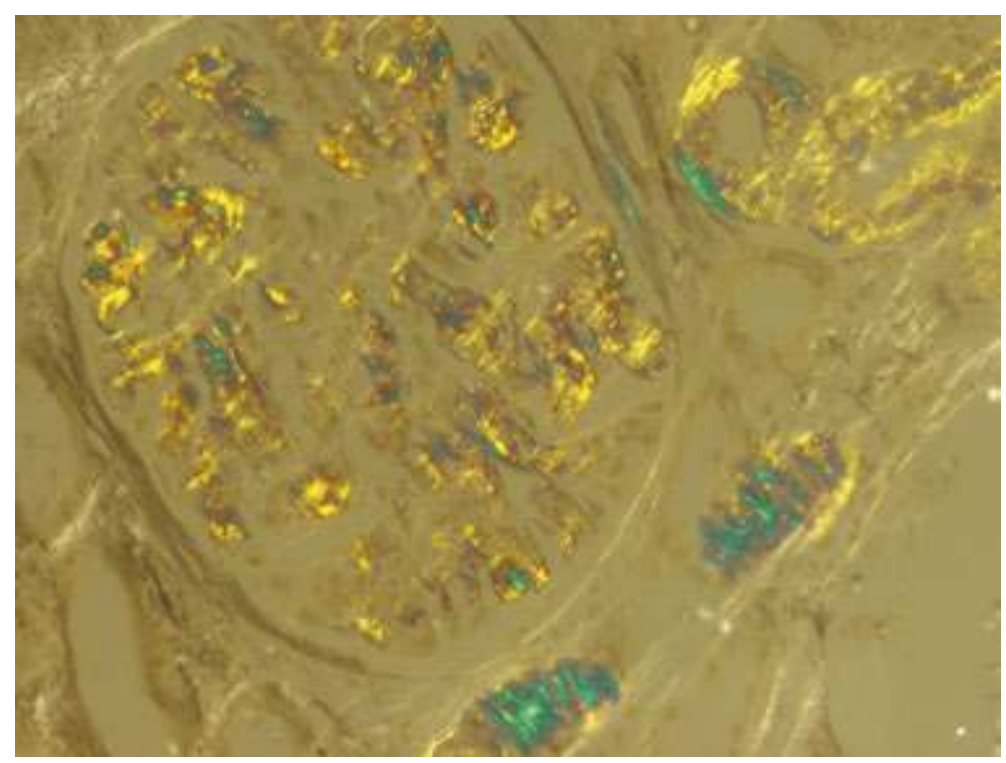

Figure 8. Amyloid deposits with characteristic apple green birefringence when viewed by polarized light (Congo red stain, original magnification $\times 400)$. 


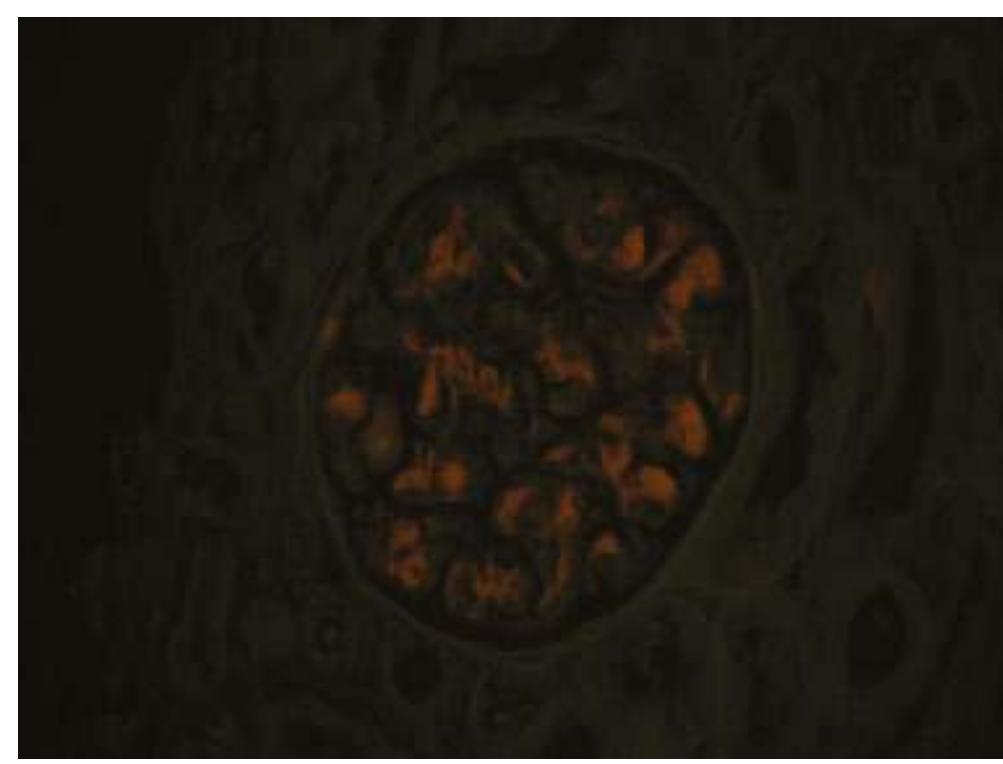

Figure 9. A small amount of amyloid deposits can be detected by placing the Congo red stained section under fluorescent light (Congo red stain, original magnification $\times 400$ ).

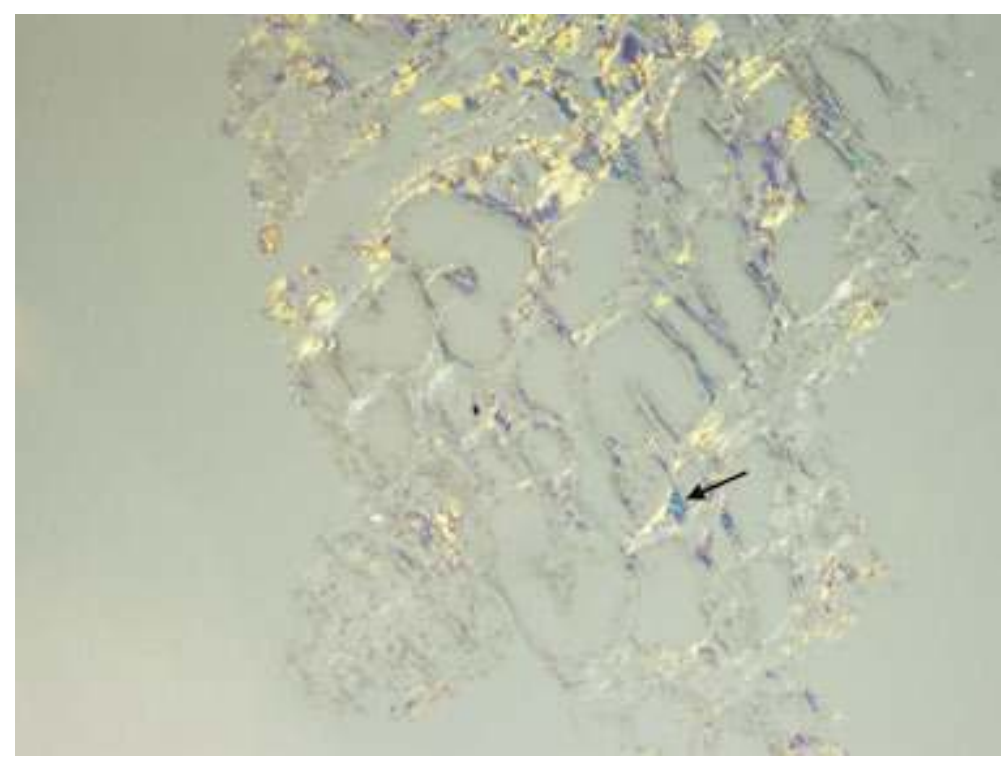

Figure 10. Congo red stain performed on frozen tissue with green birefringence (arrow) when viewed by polarized light (Congo red stain, original magnification $\times 400$ ). 
Thioflavin $\mathrm{T}$ is an additional sensitive but nonspecific fluorescent stain for amyloid, which is activated by blue light to emit yellow green fluorescence staining upon binding to amyloid [42]. This test is more sensitive than Congo red in detecting a small amount of amyloid deposits. However, due to lack of specificity, it must be confirmed by Congo red apple green birefringence, IF, IHC, and/or EM.

AL amyloid nephropathy may coexist with other manifestations of the monoclonal protein, such as light-chain cast nephropathy, light-chain proximal tubulopathy, and rarely monoclonal immunoglobulin deposition disease. Any amyloid type may have coexisting other conditions in the kidney biopsy, such as acute tubular necrosis, diabetic nephropathy, thin basement membrane lesion, or arterionephrosclerosis.

\subsection{Immunofluorescence microscopy}

Immunofluorescence (IF) microscopy or immunohistochemistry is crucial for confirming the presence and for typing of amyloid nephropathy. IF is useful for detection of amyloid derived from Ig light and heavy chains. Amyloid deposits have a distinctive smudgy appearance of staining (Figure 11a). Restriction for light chain, either kappa or more commonly lambda, or for heavy-chain determents $(\gamma$ or $\mu$ ) must be demonstrated, in association with Congo red positivity, for a diagnosis of AIg amyloidosis. Therefore, IF staining for kappa and lambda should be routinely performed on all native renal biopsies. The findings of strong staining for a monoclonal Ig light chain with negativity for Ig heavy chains is diagnostic of AL nephropathy (Figure 11a and $\mathbf{b}$ ). About $75 \%$ of AL nephropathy cases are due to monoclonal lambda deposits. The diagnosis of AH nephropathy is based on the presence of strong staining for a single Ig heavy chain with negativity for kappa and lambda light chains (Figure 12). AHL nephropathy shows intense staining for Ig heavy chain and a single Ig light chain (Figure 13a and $\mathbf{b})$.
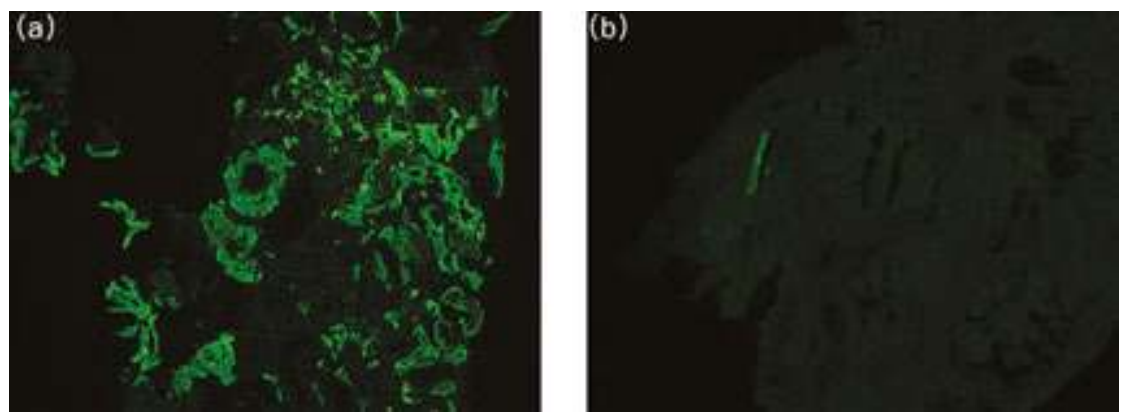

Figure 11. AL nephropathy with smudgy mesangial, vascular, and interstitial staining for lambda (a) and negative kappa (b) (IF, original magnification $\times 400)$.

In addition to specific staining for proteins that comprise the amyloid, amyloid deposits often have low levels of nonspecific trapping with several reagent antibodies, including Ig and complements (Figure 14a and b). This varies, with different reagent antibodies and different 
specimens, and is more common with AA nephropathy than AL nephropathy. The basis for this low level of staining is not well understood, but may result from charge interaction between the amyloid and the reagent antibodies, contamination with serum proteins, and/or humoral reaction directed against amyloid fibrils. These low levels of nonspecific trapping sometime render the distinction between AA nephropathy and AL/AH/AHL nephropathy difficult. About $21 \%$ of AA nephropathy cases from a study by Nasr et al. [8] could not be diagnosed with certainty by IF and needed confirmation of amyloid type by mass spectrometry.

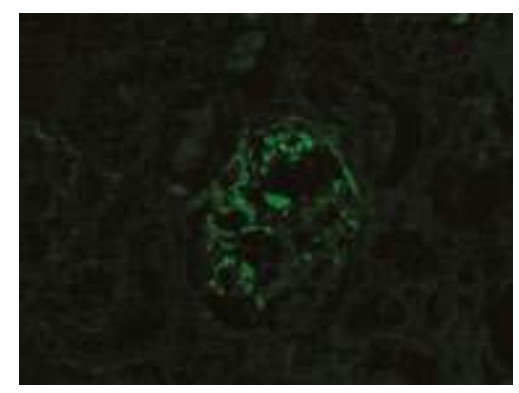

Figure 12. AH nephropathy. Intense glomerular staining for IgG heavy chain. Kappa and lambda are negative (IF, original magnification $\times 400$ ).
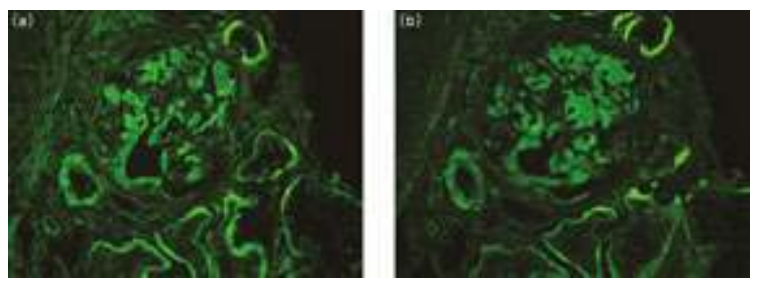

Figure 13. AHL nephropathy. Intense glomerular, vascular and tubular basement membrane staining for IgG heavy chain (a) and lambda light chain (b). Kappa is negative (IF, original magnification $\times 400$ ).
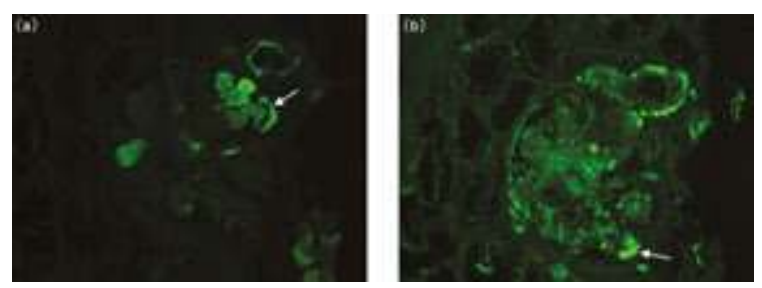

Figure 14. Low level of non-specific staining for Immunoglobulin M (IgM) (a, arrow) and complement 3 (C3) (b, arrow) in AA nephropathy (IF, original magnification $\times 400)$. 


\subsection{Electron microscopy}

Transmission electron microscopy (TEM) is helpful in confirming the diagnosis of amyloidosis, but it is not helpful in determining the type of amyloid. At low magnification, amyloid deposits have a characteristic cottony appearance (Figure 15) that should alert the pathologist to investigate at higher magnification the possibility of amyloidosis. At high magnification, amyloid is composed of randomly arranged, elongated fibrils that measure 8-12 nm in diameter (Figure 16). Amyloid fibrils are associated with smaller, round structures, namely, amyloid p component. The fibrils are extracellular and located near mesangial cells in glomeruli and myocytes in the media of vessel walls in amyloid nephropathy. The amyloid

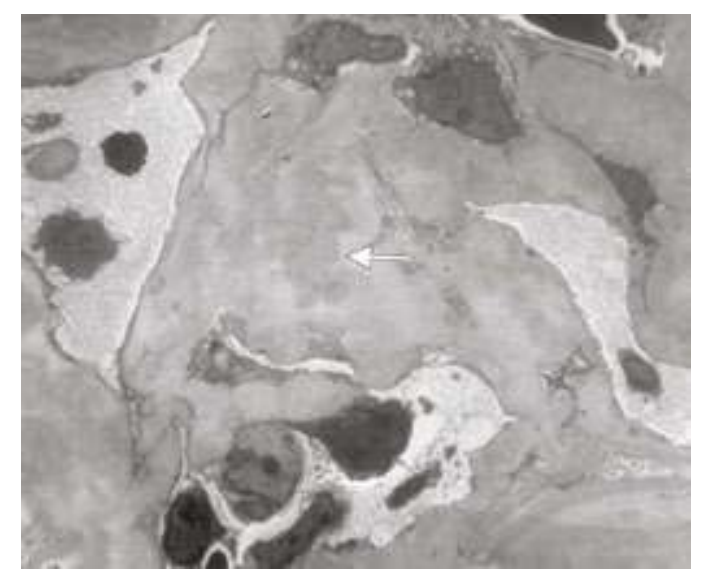

Figure 15. Extensive expansion of the mesangium by amyloid, which shows lumpy cottony appearance (arrow) on low power electron microscopy (transmission electron microscopy (TEM), original magnification, $\times 5600$ ).

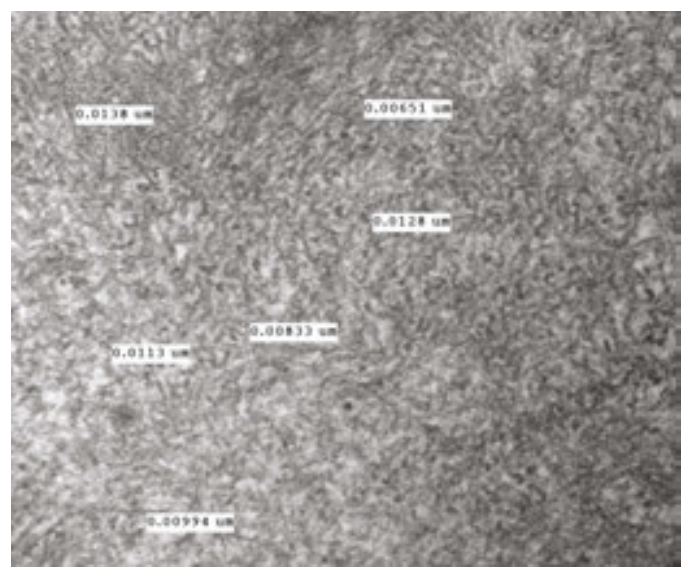

Figure 16. AL nephropathy. Amyloid fibrils replacing normal mesangium. Typical amyloid fibrils are randomly arranged, nonbranching and measure $8-12 \mathrm{~nm}$ in diameter (TEM, original magnification, $\times 14,000$ ). 
fibrils may extend into the capillary walls and thus, foot process effacement is commonly seen in the segments of glomerular basement membranes overlying amyloid deposits. The podocyte cytoplasm adjacent to the amyloid deposits often shows condensation of actin cytoskeleton. When amyloid deposits extend into the subepithelial zone, the fibrils usually show parallel alignment (Figure 17). This is the basis for the JMS-positive feathery spikes that may be seen by light microscopy (LM).

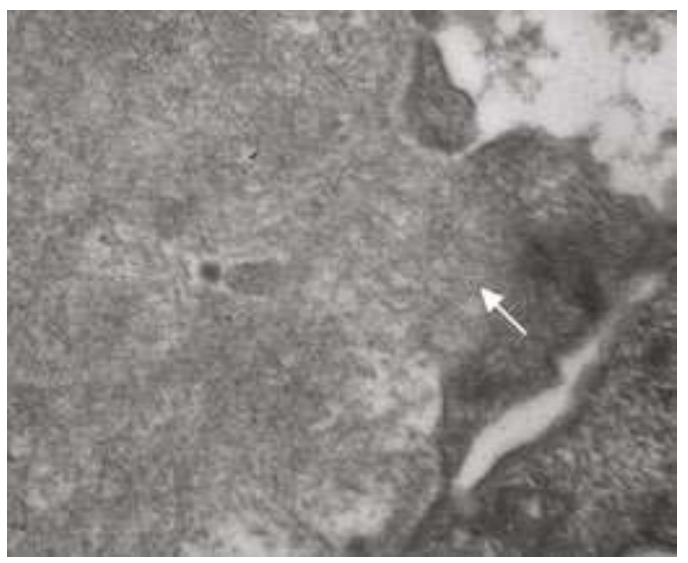

Figure 17. Alignment of amyloid fibrils (arrow) in the subepithelial zone of a glomerular basement membrane. This is the basis for the JMS-positive feathery spikes that may be seen by LM (TEM, original magnification, $\times 5600$ ).

\subsection{Differential diagnosis}

The differential diagnosis and distinction from other glomerular diseases are summarized in Table 2. By LM, the differential diagnosis includes any disease process that induces accumulation of acellular eosinophilic material in glomeruli, blood vessels, and interstitium. Accumulations of collagenous matrix, as in Kimmelstiel-Wilson nodules in diabetic nephropathy or sclerosis secondary to chronic immune complex glomerulonephritis or hypertensive nephrosclerosis, usually can be readily distinguished from amyloid by routine staining. As mentioned earlier, amyloid stains weakly with PAS and very little or negative with JMS, whereas sclerotic matrix is strongly PAS and JMS positive. Extensive glomerular deposits present in immune complex glomerulonephritis, fibrillary glomerulonephritis, immunotactoid glomerulopathy, and collagenofibrotic glomerulopathy may mimic amyloidosis on H\&E stained sections; however, special stains, IHC, and EM demonstrate the distinctive features of each of these diseases. The Congo red stain is then necessary to confirm the diagnosis of amyloid nephropathy.

Light-chain deposition disease (LCDD) shares monoclonal immunoglobulin light-chain staining with AL nephropathy, but the pattern of staining is much different. LCDD typically has a more diffuse and regular distribution of staining that appears linear or ribbon-like along glomerular and tubular basement membranes. The expanded mesangium also shows globular 
staining in LCDD, in contrast to AL nephropathy, which typically shows a smudgy pattern of lambda or kappa light-chain staining with fuzzy border in the mesangium or along glomerular basement membranes, but no ribbon-like tubular basement membrane deposits.

\begin{tabular}{|c|c|c|c|c|}
\hline $\begin{array}{l}\text { Differential } \\
\text { diagnosis }\end{array}$ & $\begin{array}{l}\text { Congo red } \\
\text { stain }\end{array}$ & LM & IF & EM \\
\hline $\begin{array}{l}\text { Light-chain } \\
\text { deposition } \\
\text { disease }\end{array}$ & Negative & $\begin{array}{l}\text { Deposition of PAS } \\
\text { positive } \\
\text { and argyrophilic material } \\
\text { in mesangium with } \\
\text { occasional nodular } \\
\text { formation }\end{array}$ & $\begin{array}{l}\text { Diffuse intense staining } \\
\text { of single light chain } \\
\text { (more often kappa) along } \\
\text { tubular and/or } \\
\text { glomerular basement } \\
\text { membranes (ribbon-like), } \\
\text { involving mesangium } \\
\text { (globular), and blood } \\
\text { vessels }\end{array}$ & $\begin{array}{l}\text { Finely granular (punctate) or } \\
\text { amorphous electron dense } \\
\text { deposits along the inner aspect } \\
\text { of glomerular basement } \\
\text { membranes and outer aspect of } \\
\text { tubular basement membranes }\end{array}$ \\
\hline $\begin{array}{l}\text { Light- and heavy- } \\
\text { chain deposition } \\
\text { disease }\end{array}$ & Negative & $\begin{array}{l}\text { Deposition of PAS } \\
\text { positive } \\
\text { and argyrophilic } \\
\text { material in mesangium } \\
\text { with occasional nodular } \\
\text { formation, } \\
\text { more mesangial } \\
\text { hypercellularity }\end{array}$ & $\begin{array}{l}\text { Diffuse intense staining } \\
\text { of single Ig heavy chain } \\
\text { (more often IgG) and a } \\
\text { single light chain along } \\
\text { tubular and/or } \\
\text { glomerular basement } \\
\text { membranes (ribbon-like), } \\
\text { involving mesangium } \\
\text { (globular), and blood } \\
\text { vessels }\end{array}$ & $\begin{array}{l}\text { Finely granular (punctate) or } \\
\text { amorphous electron dense } \\
\text { deposits along the inner aspect } \\
\text { of glomerular basement } \\
\text { membranes and outer aspect of } \\
\text { tubular basement membranes, } \\
\text { occasional immune complex- } \\
\text { type deposits, or rarely no } \\
\text { electron deposits detected }\end{array}$ \\
\hline $\begin{array}{l}\text { Heavy-chain } \\
\text { deposition } \\
\text { disease }\end{array}$ & Negative & $\begin{array}{l}\text { Deposition of PAS } \\
\text { positive and } \\
\text { argyrophilic material in } \\
\text { mesangium with } \\
\text { occasional nodular } \\
\text { formation, } \\
\text { more mesangial } \\
\text { hypercellularity }\end{array}$ & $\begin{array}{l}\text { Diffuse intense staining } \\
\text { of single Ig heavy chain } \\
\text { (more IgG3) along } \\
\text { tubular and/or } \\
\text { glomerular basement } \\
\text { membranes (ribbon-like), } \\
\text { involving mesangium } \\
\text { (globular), and blood } \\
\text { vessels, no kappa or } \\
\text { lambda staining }\end{array}$ & $\begin{array}{l}\text { Finely granular (punctate) or } \\
\text { amorphous electron dense } \\
\text { deposits along the inner aspect } \\
\text { of glomerular basement } \\
\text { membranes and outer aspect of } \\
\text { tubular basement membranes, } \\
\text { occasional immune complex- } \\
\text { type deposits, or rarely no } \\
\text { electron deposits detected }\end{array}$ \\
\hline Fibrillary GN & Negative & $\begin{array}{l}\text { Deposition of PAS } \\
\text { positive and } \\
\text { nonargyrophilic in } \\
\text { mesangium and } \\
\text { occasionally along } \\
\text { glomerular basement } \\
\text { membranes }\end{array}$ & $\begin{array}{l}\text { Smudgy staining for IgG } \\
\text { (more often IgG4), C3, } \\
\text { kappa, and lambda in } \\
\text { mesangium and along } \\
\text { capillary loops, about } \\
\text { 10\% show restriction of } \\
\text { light-chain staining }\end{array}$ & $\begin{array}{l}\text { Randomly arranged } \\
\text { nonbranching fibrils size of } \\
12-27 \mathrm{~nm} \text { in diameter within } \\
\text { mesangium, along outer aspect } \\
\text { of glomerular basement } \\
\text { membranes, and rarely along } \\
\text { tubular basement membranes }\end{array}$ \\
\hline $\begin{array}{l}\text { Immunotactoid } \\
\text { glomerulopathy }\end{array}$ & Negative & $\begin{array}{l}\text { Deposition of PAS } \\
\text { positive and } \\
\text { nonargyrophilic in }\end{array}$ & $\begin{array}{l}\text { Smudgy staining for IgG } \\
\text { (more often IgG1), C3, } \\
\text { with light chain }\end{array}$ & $\begin{array}{l}\text { Microtubular or cylindrical } \\
\text { structure with hollow cores with } \\
\text { a size from } 20 \text { to } 90 \mathrm{~nm} \text { in }\end{array}$ \\
\hline
\end{tabular}




\begin{tabular}{|c|c|c|c|c|}
\hline $\begin{array}{l}\text { Differential } \\
\text { diagnosis }\end{array}$ & $\begin{array}{l}\text { Congo red } \\
\text { stain }\end{array}$ & LM & IF & EM \\
\hline & & $\begin{array}{l}\text { mesangium and } \\
\text { occasionally along } \\
\text { glomerular basement } \\
\text { membranes }\end{array}$ & $\begin{array}{l}\text { restriction (more kappa), } \\
\text { staining in mesangium } \\
\text { and capillary loops }\end{array}$ & $\begin{array}{l}\text { diameter, arranged in parallel } \\
\text { arrays, predominantly present in } \\
\text { mesangium and subepithelial } \\
\text { zone }\end{array}$ \\
\hline $\begin{array}{l}\text { Diabetic } \\
\text { nephropathy }\end{array}$ & Negative & $\begin{array}{l}\text { Accumulation of PAS } \\
\text { positive and argyrophilic } \\
\text { glycosylate products, } \\
\text { Kimmelstiel-Wilson } \\
\text { nodules, prominent } \\
\text { glomerular basement } \\
\text { membranes }\end{array}$ & $\begin{array}{l}\text { Linear accentuation of } \\
\text { IgG and albumin along } \\
\text { glomerular and tubular } \\
\text { basement membranes }\end{array}$ & $\begin{array}{l}\text { Diabetic fibrillosis with } \\
\text { branching fibrils with a size of } \\
10-25 \mathrm{~nm} \text { in diameter in } \\
\text { mesangium, thickened } \\
\text { glomerular basement } \\
\text { membranes }\end{array}$ \\
\hline $\begin{array}{l}\text { Collagenofibrotic } \\
\text { glomerulopathy }\end{array}$ & Negative & $\begin{array}{l}\text { Increase in mesangial } \\
\text { matrix, argyrophilic, } \\
\text { PAS positive material } \\
\text { with intense blue } \\
\text { staining on Masson } \\
\text { trichrome stain }\end{array}$ & Negative staining & $\begin{array}{l}\text { curved and frayed, sometimes } \\
\text { worm-like of comma-shaped } \\
\text { fibers with transverse band } \\
\text { structure with periodicity of } 43- \\
65 \text { nm when sectioned } \\
\text { transversely }\end{array}$ \\
\hline $\begin{array}{l}\text { Fibronectin } \\
\text { glomerulopathy }\end{array}$ & Negative & $\begin{array}{l}\text { Mesangial matrix } \\
\text { accumulation of } \\
\text { nonargyrophilic material } \\
\text { with bright red staining } \\
\text { on Masson trichrome } \\
\text { stain }\end{array}$ & $\begin{array}{l}\text { May have nonspecific } \\
\text { staining for } \operatorname{IgG}, \operatorname{IgM} \text {, } \\
\text { and C3 }\end{array}$ & $\begin{array}{l}\text { Granular to fibrillary } \\
\text { substructures with a size of } 14- \\
16 \mathrm{~nm} \text { in diameter }\end{array}$ \\
\hline
\end{tabular}

Table 2. Histologic differential diagnosis of amyloid nephropathy.

By EM, the differential diagnosis includes other renal diseases that have deposits containing organized fibrillary or microtubular substructures, including fibrillary glomerulonephritis, immunotactoid glomerulopathy, and collagenofibrotic glomerulopathy. Fibrillary glomerulonephritis is characterized by glomerular deposits composed of randomly arranged, nonbranching fibrils that usually are $12-27 \mathrm{~nm}$ in diameter (Figure 18). The diagnosis of amyloidosis is unlikely if fibrils are larger than $20 \mathrm{~nm}$. Immunotactoid glomerulopathy has organized microtubular substructures with hollow cores, measuring 20-90 nm (Figure 19). Collagenofibrotic glomerulopathy shows collagen fibrils deposited predominantly in the mesangium but sometimes can extend to subendothelial zone. The collagen fibrils appear curved and often frayed with periodicity of 43-65 nm. In diabetic fibrillosis, the fibrils are 10$25 \mathrm{~nm}$, negative for Congo red and Thioflavin T. These fibrils tend to be shorter and more often aligned in parallel, slightly curved, and sometimes are oriented at right angles to mesangial cell surfaces, and may touch plasma membranes (Figure 20). Of note, the presence of diabetic fibrillosis in diabetic nephropathy does not appear to have any specific clinical connotations because a patient with this disorder behaves similarly clinically to those without fibrils [36]. For each of the above conditions with substructure of material by EM, IF and light microscopic appearances, and negative Congo red stain, allow distinction from amyloidosis. 


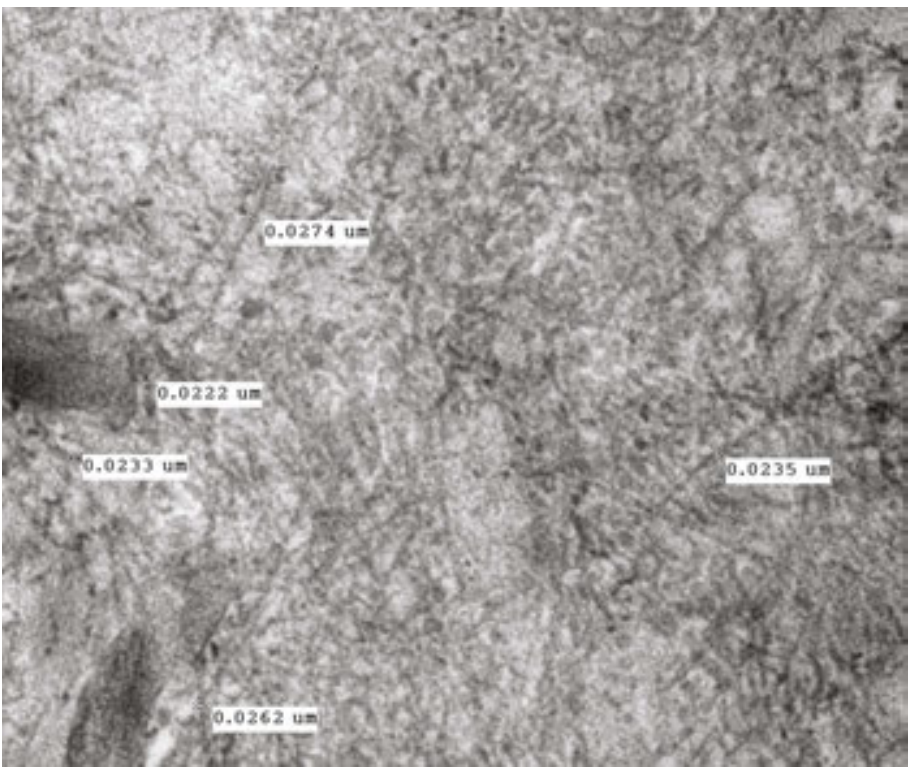

Figure 18. Fibrillary glomerulonephritis with randomly arranged nonbranching fibrils that measure $12-27 \mathrm{~nm}$ in diameter (TEM, original magnification, $\times 14,000)$.

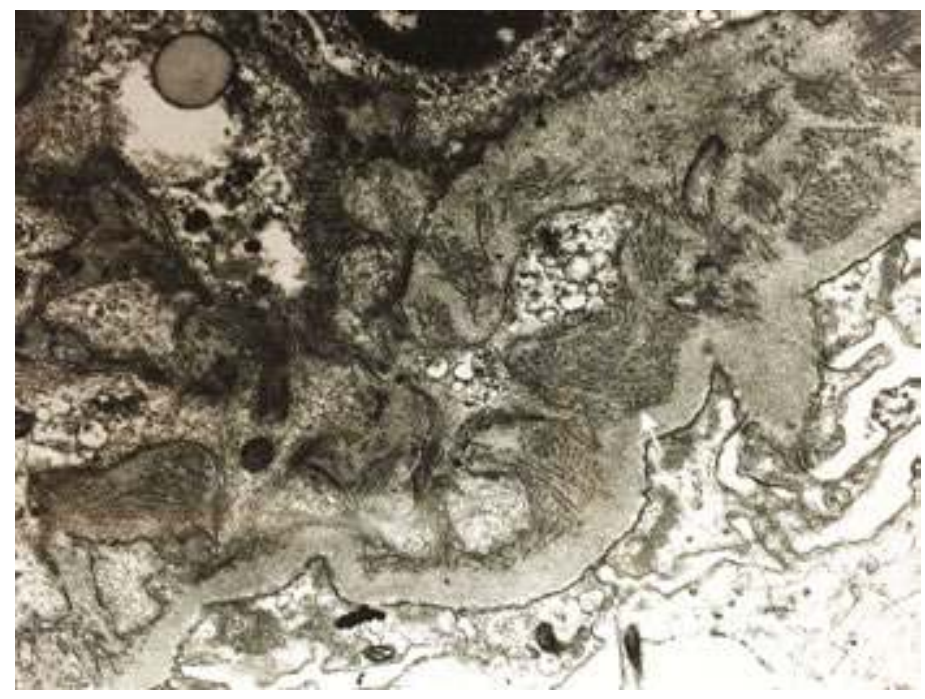

Figure 19. Immunotactoid glomerulopathy. Replacement of mesangial matrix by microtubular substructures (arrow) with hollow cores that measure $20-90 \mathrm{~nm}$ in diameter (TEM, original magnification, $\times 14,000$ ). 


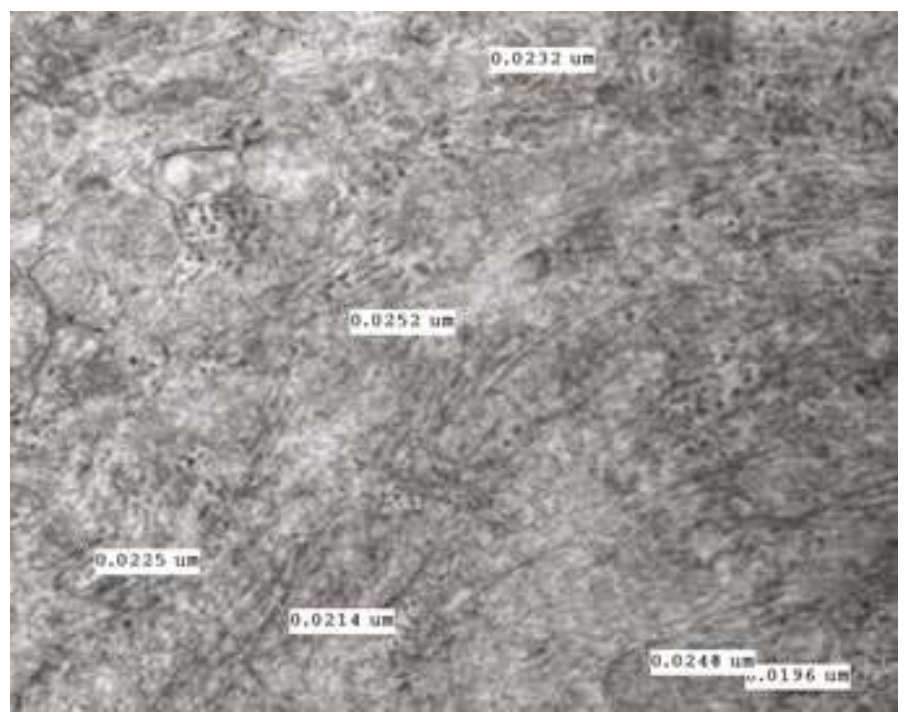

Figure 20. Diabetic fibrillosis. Replacement of mesangial matrix by short nonbranching fibrils that measure 10-25 $\mathrm{nm}$ in diameter. These fibrils tend to be more often aligned in parallel, slightly curved, and sometimes are oriented at right angles to mesangial cell surfaces (TEM, original magnification, $\times 14,000$ ).

\subsection{Typing of amyloid does matter}

Amyloid typing is absolutely crucial for clinical management in order to avoid misdiagnosis and inappropriate, potentially harmful treatment, to assess prognosis and to offer genetic counseling if relevant. The classification is based on the nature of amyloid precursor plasma proteins. The initial step is IF, which is an important technique for AL typing. In AL nephropathy, there is restriction for either kappa or lambda light chain. In AH nephropathy, the deposits stain only a single subclass of Ig heavy chain, whereas a single heavy-chain and a single light-chain stain positive in AHL nephropathy. In cases where no frozen tissue is available, IF can be performed on paraffin embedded tissue by a pronase-digested technique. The paraffin-embedded tissue pronase-digested technique has less sensitivity than frozen tissue IF. Thus, negative IF staining for Ig light chains or heavy chain does not completely rule out AL nephropathy, AH nephropathy, or AHL nephropathy, as some monoclonal proteins may be mutated and not recognized by commercial antibodies. However, a negative IF study does typically suggest another type of amyloid nephropathy and requires further exploration by other modalities to diagnose the type of amyloid.

Current diagnostic methods, such as IHC technique using antibody-based amyloid typing, have limited ability to detect the full spectrum of amyloid forming proteins. Although IHC can be performed using commercially available antibodies against amyloid of the classes AL, $\mathrm{AH}, \mathrm{AA}, \mathrm{AFib}, \mathrm{ATTR}, \mathrm{AApo} \mathrm{AI}$, and A $\beta 2 \mathrm{M}[10]$, of these antibodies, serum amyloid A (SAA) IHC on paraffin-embedded tissue is the most extensively used and is considered the gold 
standard technique for diagnosing AA (Figure 21). AA IHC reveals a pattern of distribution matching that seen by LM. From our study, IHC on paraffin-embedded tissue for LECT2 is sensitive; however, it is not entirely specific for ALECT2 [41]. It is recommended that the diagnosis of ALECT2 nephropathy should be confirmed by mass spectrometry analysis of renal tissues when the staining pattern shows equivocal Intensity [41].

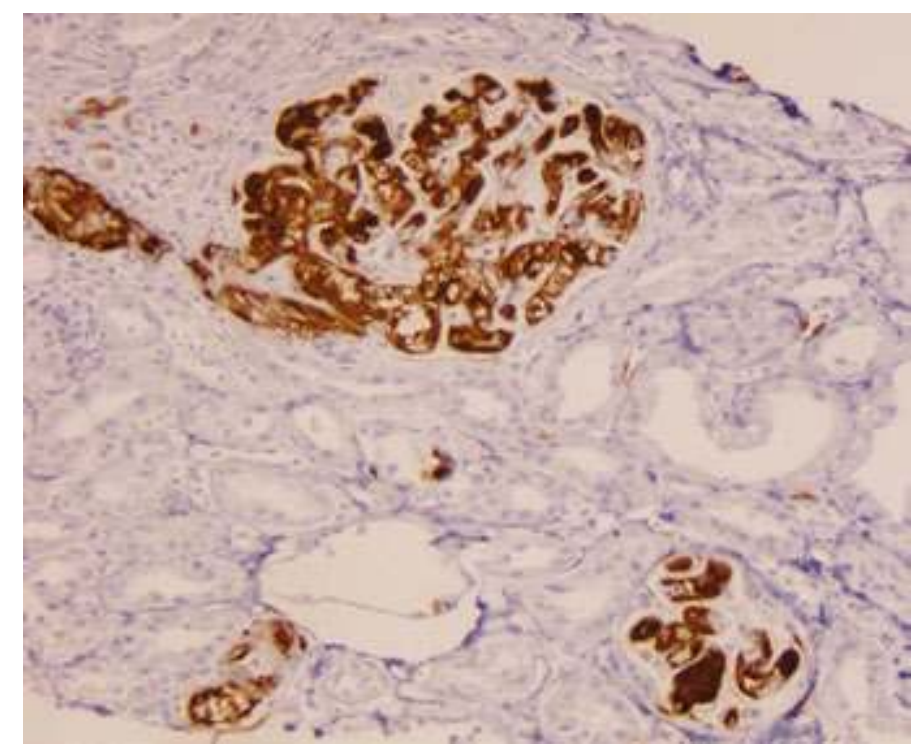

Figure 21. AA nephropathy with intense glomerular and vascular staining for SAA IHC (anti-SAA IHC, original magnification $\times 200)$.

In spite of the availability of IF and IHC, there are multiple drawbacks of these methods, such as sensitivity and specificity of commercial antibodies that are designed against only nonmutated proteins. Mutant proteins and proteins with conformational changes might be less reactive to commercial antibodies [39]. For example, in 7-35\% of the AL nephropathy cases, the amyloid deposits were negative for both kappa and lambda IF staining on frozen tissue [7]. Therefore, be aware that a negative staining for light- and/or heavy-chain IF does not exclude AIg nephropathy. Of note, rare cases of amyloid nephropathy show more than one type of amyloid protein, leading to difficulty in typing. The drawbacks of these techniques may be solved by mass spectrometry, which is discussed below.

\subsection{Proteomics}

The direct technique of amyloid demonstration is based on proteomic analysis using laser microdissection/mass spectrometry (LMD/MS), which has the capability for identification of the many different proteins [43]. This technique has a high sensitivity and specificity and solves many of the problems presented by other techniques [44]. 
LMD/MS has proved to be useful to determine the nature and type of the amyloid precursor protein in cases that could not be typed by routine IHC panels $[45,46]$. The major advantage of LMD/MS over conventional IHC techniques in typing of amyloid is that LMD/MS is a single test that can identify and type the amyloid protein, in contrast to IHC that may require several antibodies staining multiple sections [47]. Furthermore, LMD/MS is performed from paraffin-embedded tissue and requires no special treatment. The common indications for LMD/MS in amyloid nephropathy include amyloid type confirmation, insufficient tissue sample for IF or IHC studies but with remaining tissue in paraffin block, difficult cases on routine renal biopsy studies such as heavy-chain amyloidosis and familial and hereditary forms of amyloidosis [17, 48, 49]. The diagnosis of amyloidosis at the proteomic level using LMD/MS is purely based on the presence of large spectra of proteins, which have amyloidogenic properties, in addition to apolipoprotein E (Apo E) and SAP that are commonly present in all types of amyloid [40]. Therefore, in AA nephropathy, large spectra numbers of serum amyloidassociated protein along with Apo E and SAP are present. In contrast, in ALECT2 and AGel nephropathy, large spectra numbers of LECT2 and gelsolin are present along with Apo E and SAP.

LMD/MS has been very helpful in achieving amyloid typing from formalin-fixed paraffinembedded tissue. LMD/MS has also been critical for the typing of cases with limited antibody reactivity and in the discovery of new protein types of amyloid. From a study by Said et al., the type of amyloid in $16 \%$ of amyloid nephropathy cases could not have been typed without LMD/MS [8]. In spite of these major advantages, LMD/MS also has a few drawbacks. As mentioned above, identification of amyloid proteins is purely based on the presence of large spectra for proteins, which have amyloidogenic properties within the analyzed sample. In a case of focal amyloidosis, a small amount of amyloid deposit may be obscured by Apo E, SAP, and various serum proteins. Furthermore, the observed peptide fragmentation data must be matched to known protein sequences that are available in the public data base, and thus, unknown protein sequences due to certain germ line polymorphisms or somatic mutations, may not be identified. Despite these drawbacks, the number of cases of amyloid with undetermined type has markedly decreased with use of this technique to $7 \%$, with $3 \%$ of the sample insufficient for analysis $[7,8,50]$

\subsection{Treatment and prognosis}

The goal of current treatment approaches for AIg nephropathy is to eradicate the clone of plasma cells that produce amyloidogenic monoclonal light chains, Ig heavy chain, and Ig heavy and light chain. Patients with AIg nephropathy are usually treated with chemotherapeutic regimens appropriate for B-cell or plasma cell neoplasm. Melphalan-dexamethasone-bortezomib is commonly used as frontline regimen for patients with Stages I and II cardiac involvement [51]. Patients with Stage III cardiac involvement or advanced chronic kidney disease (CKD) patients are generally treated with cyclophosphamide-bortezomib-dexamethasone [51, 52], which showed overall $81.4 \%$ hematologic response [53]. High-dose intravenous melphalan followed by autologous stem cell transplantation (HDM/ASCT) to support bone marrow recovery has emerged as the most likely to eradicate the clonal plasma cells [39]. 
Experiences from several treatment centers has suggested that $25-50 \%$ of patients who undergo such treatment have complete hematologic response, indicating that there is no evidence of ongoing production of monoclonal light chains, Ig heavy chain, or Ig heavy chain and light chain [52-54]. HDM/ASCT is generally offered to patients with Stages I or II cardiac involvement patients who have glomerular filtration rate (GFR) $\geq 30 \mathrm{~mL} / \mathrm{min}$ in the absence of advanced other organ involvement [54-56].

Treatment of the underlying chronic inflammatory diseases, such as immunosuppressive agents for rheumatoid arthritis and inflammatory bowel diseases is beneficial in patients with AA nephropathy. The basis of modern treatment in AA nephropathy is still reduction of SAA production. Additionally, steroids and cytotoxic drugs, treatment with monoclonal antibodies against cytokines, particularly tumor necrotic factors (TNF) and interleukin-6 (IL-6), are effective in many cases [57]. This approach of treatment is targeted not only at amyloid fibrils themselves but also at messengers in the acute-phase response. Other therapies, such as antisense oligonucleotides, have been suggested to specifically lower the expression of SAA in the liver [57]. AA nephropathy caused by familial Mediterranean fever responds to colchicine [58]. In familial amyloidosis, including AFib, ATTR, and AApo AI, in which the liver is the source of precursor protein, patients are treated with liver transplantation [57]. A novel drug, R-1-[6-[R-2carboxy-pyrrolidin-1-yl]-6-oxo-hexanoyl]pyrrolidine-2-carboxylic acid is a competitive inhibitor of SAP binding to amyloid fibrils [59,60]. This palindromic compound also cross-links and dimerizes SAP molecules, leading to their very rapid clearance by the liver, and hence produces a marked reduction in human SAP in the circulation [61]. This mechanism of drug action potently removes SAP from the deposits of amyloid in human tissue and may provide a new therapeutic approach to AA amyloidosis and diseases associated with local amyloid deposition, including Alzheimer's disease [61].

The prognosis for patients with AL nephropathy is generally poor and depends on systemic organ involvement, but survival can be prolonged with treatment $[62,63]$. Patients with AL nephropathy have a median overall survival of 1-2 years [62, 63]. Patients with AA nephropathy have a better prognosis than those with AL nephropathy with the median survival varies between 2 and 10 years [13, 64]. In AL nephropathy and AA nephropathy, cardiac involvement is an independent negative predictive factor of patient survival [13]. Patients with AA, $\mathrm{AH}, \mathrm{AHL}, \mathrm{AFib}$, and ALECT2 nephropathy have longer overall survival compared with AL nephropathy, largely because of a lower rate of cardiac involvement $[13,65,66]$. The mean survival for AFib is 15 years [10], and the median survival for ALECT nephropathy is 62 months [66].

In AL nephropathy, kidney transplantation is ideally performed after production of amyloidogenic light-chain proteins has been eradicated. Kidney transplantation for systemic AL patients has a relative good outcome with 1- and 5-year patient survival of $75 \%$ and $67 \%$ and median graft survival of 5.8 years [67-69]. However, amyloidosis may recur in kidney transplants, depending on the amyloid type and progression of the underlying disease. In a large series from the UK, among 246 patients with AL nephropathy with renal failure, only $10 \%$ received kidney transplants [69], and of these, amyloidosis recurred in $28 \%$; however, no graft was lost due to recurrent AL amyloidosis [67]. Patient survival was best among pa- 
tients who had achieved partial remission before kidney transplantation (8.9 years). In a French series of 59 recipients with AA amyloidosis, recurrence was documented in $14 \%$ at a median of 10 years posttransplant and was often associated with nephrotic range proteinuria [70]. Among 10 recipients with hereditary AFib amyloidosis who received kidney transplantation only, recurrent AFib amyloidosis was detected in $70 \%$ and median graft survival was 7.3 years [69]. In contrast, no recurrence was detected in the nine patients who received combined kidney and liver transplantation, but the mean renal graft survival was 6.4 years [62]. Hereditary AApo I amyloidosis has recurred in 30\% who received kidney transplantation only, and of these, one graft was lost to recurrent AApo I amyloidosis [68]. There is no effective therapy for ALECT2 nephropathy [37]. Because the precursor protein in ALECT2 is nonmutant, liver transplantation is likely ineffective [26]. Kidney transplantation has been suggested as a treatment option for ALECT2 nephropathy patients with advanced renal failure [35]. Although the disease may recur in about $20 \%$ of allografts, no graft was lost to recurrent ALECT2 nephropathy [69]. Possible future therapies for ALECT2 nephropathy include reducing the supply of LECT2 (e.g., inhibiting the Wnt/ $\beta$-catenin signal pathway), inhibiting amyloid fibril formation by blocking the binding of glycoaminoglycans to amyloid fibrils, promoting clearance of amyloid by immunotherapy, and promoting amyloid regression by SAP-targeted therapy.

\section{Acknowledgements}

The author thanks Dr. Agnes Fogo and Dr. Mark Lusco for their helpful advice.

\section{Author details}

Paisit Paueksakon

Address all correspondence to: paisit.paueksakon@vanderbilt.edu

Department of Pathology, Microbiology, and Immunology, Vanderbilt University Medical Center, Nashville, TN, USA

\section{References}

[1] Kisilevsky R. Amyloid and amyloidoses: differences, common themes, and practical considerations. Mod Pathol. 1991; 4(4): 514-8.

[2] Thornton C. Amyloid disease. An autopsy review of the decades 1937-46 and 1961-70. Ulster Med J. 1983; 52(1): 31-4. 
[3] Tuglular S, Yalcinkaya F, Paydas S, Oner A, Utas C, Bozfakioglu S, Ataman R, Akpolat T, Ok E, Sen S, Düsünsel R, Evrenkaya R, Akoglu E. A retrospective analysis for aetiology and clinical findings of 287 secondary amyloidosis cases in Turkey. Nephrol Dial Transplant. 2002; 17(11): 2003-5.

[4] Ensari C, Ensari A, Tümer N, Ertug E. Clinicopathological and epidemiological analysis of amyloidosis in Turkish patients. Nephrol Dial Transplant. 2005; 20(8): 1721-5.

[5] Lekpa FK, Ndongo S, Pouye A, Tiendrebeogo JW, Ndao AC, Ka MM, Diop TM. Amyloidosis in sub-Saharan Africa. Med Sante Trop. 2012; 22(3): 275-8.

[6] Larsen CP, Walker PD, Weiss DT, Solomon A. Prevalence and morphology of leukocyte chemotactic factor 2-associated amyloid in renal biopsies. Kidney Int. 2010 77: 816819.

[7] Sethi S, Vrana JA, Theis JD, Dogan A. Mass spectrometry based proteomics in the diagnosis of kidney disease. Curr Opin Nephrol Hypertens. 2013; 22(3):273-80.

[8] Said SM, Sethi S, Valeri AM, Leung N, Cornell LD, Fidler ME, Herrera Hernandez L, Vrana JA, Theis JD, Quint PS, Dogan A, Nasr SH. Renal amyloidosis: origin and clinicopathologic correlations of 474 recent cases. Clin J Am Soc Nephrol. 2013; 8(9): 1515-23.

[9] Manabe S, Hatano M, Yazaki M, Nitta K, Nagata M. Renal AH amyloidosis associated with a truncated immunoglobulin heavy chain undetectable by immunostaining. Am J Kidney Dis. 2015; 66(6): 1095-100.

[10] Markowitz GS. Dysproteinemia and the kidney. Adv Anat Pathol. 2004; 11(1): 49-63.

[11] von Hutten H, Mihatsch M, Lobeck H, Rudolph B, Eriksson M, Röcken C. Prevalence and origin of amyloid in kidney biopsies. Am J Surg Pathol. 2009; 33: 1198-1205.

[12] Gillmore JD, Lachmann HJ, Rowczenio D, Gilbertson JA, Zeng CH, Liu ZH, Li LS, Wechalekar A, Hawkins PN. Diagnosis, pathogenesis, treatment, and prognosis of hereditary fibrinogen A alpha-chain amyloidosis. J Am Soc Nephrol. 2009; 20(2): 44451.

[13] Bergesio F, Ciciani AM, Manganaro M, Palladini G, Santostefano M, Brugnano R, Di Palma AM, Gallo M, Rosati A, Tosi PL, Salvadori M.; Immunopathology Group of the Italian Society of Nephrology. Renal involvement in systemic amyloidosis: an Italian collaborative study on survival and renal outcome. Nephrol Dial Transplant. 2008; 23(3): 941-51.

[14] Sethi S, Thesis JD, Quint P, Maierhofer W, Kurtin PJ, Dogan A, Highsmith EW Jr. Renal amyloidosis associated with a novel sequence variant of gelsolin. Am J Kidney Dis. 2013; 1: 161-166. 
[15] Soutar AK, Hawkins PN, Vigushin DM, Tennent GA, Booth SE, Hutton T, Nguyen O, Totty NF, Feest TG, Hsuan JJ, et al. Apolipoprotein AI mutation Arg-60 causes autosomal dominant amyloidosis. Proc Natl Acad Sci U S A. 1992; 89(16): 7389-93.

[16] Yazaki M, Liepnieks JJ, Yamashita T, Guenther B, Skinner M, Benson MD. Renal amyloidosis caused by a novel stop-codon mutation in the apolipoprotein A-II gene. Kidney Int. 2001; 60(5): 1658-65.

[17] Sethi S, Theis JD, Shiller SM, Nast CC, Harrison D, Rennke HG, Vrana JA, Dogan A. Medullary amyloidosis associated with apolipoprotein A-IV deposition. Kidney Int. 2012; 81(2): 201-6.

[18] Benson MD, James S, Scott K, Liepnieks JJ, Kluve-Beckerman B. Leukocyte chemotactic factor 2: a novel renal amyloid protein. Kidney Int. 2008 Jul;74(2):218-22.

[19] Kyle RA, Gertz MA. Primary systemic amyloidosis: clinical and laboratory features in 474 cases. Semin Hematol. 1995; 32(1): 45-59.

[20] Fu J, Seldin DC, Berk JL, Sun F, O’Hara C, Cui H, Sanchorawala V. Lymphadenopathy as a manifestation of amyloidosis: a case series. Amyloid. 2014; 21(4): 256-60.

[21] Loo D, Mollee PN, Renaut P, Hill MM. Proteomics in molecular diagnosis: typing of amyloidosis. J Biomed Biotechnol. 2011; 754109.

[22] Merlini G, Bellotti V. Molecular mechanisms of amyloidosis. N Engl J Med. 2003;349(6): 583-96.

[23] Ozaki S, Abe M, Wolfenbarger D, Weiss DT, Solomon A. Preferential expression of human lambda-light-chain variable-region subgroups in multiple myeloma, AL amyloidosis, and Waldenström's macroglobulinemia. Clin Immunol Immunopathol. 1994; 71(2): 183-9.

[24] Solomon A, Frangione B, Franklin EC. Bence Jones proteins and light chains of immunoglobulins. Preferential association of the V lambda VI subgroup of human light chains with amyloidosis AL (lambda). J Clin Invest. 1982; 70(2): 453-60.

[25] Hurle MR, Helms LR, Li L, Chan W, Wetzel R. A role for destabilizing amino acid replacements in light-chain amyloidosis. Proc Natl Acad Sci U S A. 1994; 91(12): 544650 .

[26] McCutchen SL, Lai Z, Miroy GJ, Kelly JW, Colón W. Comparison of lethal and nonlethal transthyretin variants and their relationship to amyloid disease. Biochemistry. 1995; 34(41): 13527-36.

[27] Booth DR, Sunde M, Bellotti V, Robinson CV, Hutchinson WL, Fraser PE, Hawkins PN, Dobson CM, Radford SE, Blake CC, Pepys MB. Instability, unfolding and aggregation of human lysozyme variants underlying amyloid fibrillogenesis. Nature. 1997; 385(6619): 787-93. 
[28] Hardy J, Selkoe DJ. The amyloid hypothesis of Alzheimer's disease: progress and problems on the road to therapeutics. Science. 2002; 297(5580): 353-6.

[29] McLaurin J, Yang D, Yip CM, Fraser PE. Review: modulating factors in amyloid-beta fibril formation. Struct Biol. 2000; 130(2-3): 259-70.

[30] Kisilevsky R, Manley PN. Acute-phase serum amyloid A: perspectives on its physiological and pathological roles. Amyloid. 2012;19 (1): 5-14.

[31] Verdone G, Corazza A, Viglino P, Pettirossi F, Giorgetti S, Mangione P, Andreola A, Stoppini M, Bellotti V, Esposito G. The solution structure of human beta2-microglobulin reveals the prodromes of its amyloid transition. Protein Sci. 2002; 11(3): 487-99.

[32] Scholefield Z, Yates EA, Wayne G, Amour A, McDowell W, Turnbull JE. Heparan sulfate regulates amyloid precursor protein processing by BACE1, the Alzheimer's beta-secretase. J Cell Biol. 2003; 163(1): 97-107.

[33] Ding Y, Kim JK, Kim SI, Na HJ, Jun SY, Lee SJ, Choi ME. TGF-\{beta\}1 protects against mesangial cell apoptosis via induction of autophagy. J Biol Chem. 2010; 285(48): 37909_ 19.

[34] Teng J, Russell WJ, Gu X, Cardelli J, Jones ML, Herrera GA. Different types of glomerulopathic light chains interact with mesangial cells using a common receptor but exhibit different intracellular trafficking patterns. Lab Invest. 2004; 84(4): 440-51.

[35] Teng J, Turbat-Herrera EA, Herrera GA. Extrusion of amyloid fibrils to the extracellular space in experimental mesangial AL-amyloidosis: transmission and scanning electron microscopy studies and correlation with renal biopsy observations. Ultrastruct Pathol. 2014;38(2):104-15.

[36] Herrera GA, Turbat-Herrera EA. Renal diseases with organized deposits: an algorithmic approach to classification and clinicopathologic diagnosis. Arch Pathol Lab Med. 2010; 134(4): 512-31.

[37] Nasr SH, Dogan A, Larsen CP. Leukocyte cell-derived chemotaxin 2-associated amyloidosis: a recently recognized disease with distinct clinicopathologic characteristics. Clin J Am Soc Nephrol. 2015; 10(11): 2084-93.

[38] Richards DB, Cookson LM, Berges AC, Barton SV, Lane T, Ritter JM, Fontana M, Moon JC, Pinzani M, Gillmore JD, Hawkins PN, Pepys MB. Therapeutic clearance of amyloid by antibodies to serum amyloid P component. N Engl J Med. 2015; 373(12): 1106-14.

[39] Dember LM. Amyloidosis-associated kidney disease. J Am Soc Nephrol. 2006; 17(12): 3458-71.

[40] Dikman SH, Churg J, Kahn T. Morphologic and clinical correlates in renal amyloidosis. Hum Pathol. 1981; 12(2): 160-9.

[41] Elghetany MT, Saleem A, Barr K. The Congo red stain revisited. Ann Clin Lab Sci. 1989; 19(3) :190-5. 
[42] Westermark GT, Johnson KH, Westermark P. Staining methods for identification of amyloid in tissue. Methods Enzymol. 1999; 309: 3-25.

[43] Paueksakon P, Fogo AB, Sethi S. Leukocyte chemotactic factor 2 amyloidosis cannot be reliably diagnosed by immunohistochemical staining. Hum Pathol. 2014; 45(7): 144550 .

[44] Leung N, Nasr SH, Sethi S. How I treat amyloidosis: the importance of accurate diagnosis and amyloid typing. Blood. 2012; 120(16): 3206-13.

[45] Sethi S, Vrana JA, Theis JD, Leung N, Sethi A, Nasr SH, Fervenza FC, Cornell LD, Fidler ME, Dogan A. Laser microdissection and mass spectrometry-based proteomics aids the diagnosis and typing of renal amyloidosis. Kidney Int. 2012; 82(2): 226-34.

[46] Vrana JA, Gamez JD, Madden BJ, Theis JD, Bergen HR 3rd, Dogan A. Classification of amyloidosis by laser microdissection and mass spectrometry-based proteomic analysis in clinical biopsy specimens. Blood. 2009; 114(24): 4957-9.

[47] Murphy CL, Wang S, Williams T, Weiss DT, Solomon A. Characterization of systemic amyloid deposits by mass spectrometry. Methods Enzymol. 2006; 412: 48-62.

[48] Murphy CL, Eulitz M, Hrncic R, Sletten K, Westermark P, Williams T, Macy SD, Wooliver C, Wall J, Weiss DT, Solomon A. Chemical typing of amyloid protein contained in formalin-fixed paraffin-embedded biopsy specimens. Am J Clin Pathol. 2001; 116(1): 135-42.

[49] Sethi S, Theis JD, Leung N, Dispenzieri A, Nasr SH, Fidler ME, Cornell LD, Gamez JD, Vrana JA, Dogan A. Mass spectrometry-based proteomic diagnosis of renal immunoglobulin heavy chain amyloidosis. Clin J Am Soc Nephrol. 2010; 5(12): 2180-7.

[50] Dogan A, Theis JD, Vrana JA. Mass spectrometry based proteomics for classification of amyloidosis. Mayo Clinic experience. In: Hazenberg BP, Bijzet J, van Gameren II, et al., eds. XIIIth International Symposium on Amyloidosis. Groningen: UMCG. 2013;183185.

[51] Kastritis E, Dimopoulos MA. Recent advances in the management of AL amyloidosis. Br J Haematol. 2016; 172(2): 170-86.

[52] Rannigan L, Gibbs SD, Pinney JH, Whelan CJ, Lachmann HJ, Gillmore JD, Hawkins PN, Wechalekar AD. Cyclophosphamide, bortezomib, and dexamethasone therapy in AL amyloidosis is associated with high clonal response rates and prolonged progression-free survival. Blood. 2012; 119(19): 4387-90.

[53] Venner CP, Lane T, Foard D, Rannigan L, Gibbs SD, Pinney JH, Whelan CJ, Lachmann HJ, Gillmore JD, Hawkins PN, Wechalekar AD. Cyclophosphamide, bortezomib, and dexamethasone therapy in AL amyloidosis is associated with high clonal response rates and prolonged progression-free survival. Blood. 2012; 119(19):4387-90.

[54] Skinner M, Sanchorawala V, Seldin DC, Dember LM, Falk RH, Berk JL, Anderson JJ, O’Hara C, Finn KT, Libbey CA, Wiesman J, Quillen K, Swan N, Wright DG. High-dose 
melphalan and autologous stem-cell transplantation in patients with AL amyloidosis: an 8-year study. Ann Intern Med. 2004; 140(2): 85-93.

[55] Gertz MA, Lacy MQ, Dispenzieri A, Gastineau DA, Chen MG, Ansell SM, Inwards DJ, Micallef IN, Tefferi A, Litzow MR. Stem cell transplantation for the management of primary systemic amyloidosis. Am J Med. 2002; 113(7): 549-55.

[56] Moreau P, Leblond V, Bourquelot P, Facon T, Huynh A, Caillot D, Hermine O, Attal M, Hamidou M, Nedellec G, Ferrant A, Audhuy B, Bataille R, Milpied N, Harousseau JL. Prognostic factors for survival and response after high-dose therapy and autologous stem cell transplantation in systemic AL amyloidosis: a report on 21 patients. Br J Haematol. 1998; 101(4):766-9.

[57] Westermark GT, Fändrich M, Westermark P. AA amyloidosis: pathogenesis and targeted therapy. Annu Rev Pathol. 2015; 10: 321-44.

[58] Meneses CF, Egües CA, Uriarte M, Belzunegui J, Rezola M. Colchicine use in isolated renal AA amyloidosis. Reumatol Clin. 2015; 11(4): 242-3.

[59] Sahota T, Berges A, Barton S, Cookson L, Zamuner S, Richards D. Target mediated drug disposition model of CPHPC in patients with systemic amyloidosis. CPT Pharmacom Syst Pharmacol. 2015; 4(2): e15.

[60] Kolstoe SE, Mangione PP, Bellotti V, Taylor GW, Tennent GA, Deroo S, Morrison AJ, Cobb AJ, Coyne A, McCammon MG, Warner TD, Mitchell J, Gill R, Smith MD, Ley SV, Robinson CV, Wood SP, Pepys MB. Trapping of palindromic ligands within native transthyretin prevents amyloid formation. Proc Natl Acad Sci U S A. 2010; 107(47): 20483-8.

[61] Pepys MB, Herbert J, Hutchinson WL, Tennent GA, Lachmann HJ, Gallimore JR, Lovat LB, Bartfai T, Alanine A, Hertel C, Hoffmann T, Jakob-Roetne R, Norcross RD, Kemp JA, Yamamura K, Suzuki M, Taylor GW, Murray S, Thompson D, Purvis A, Kolstoe S, Wood SP, Hawkins PN. Targeted pharmacological depletion of serum amyloid P component for treatment of human amyloidosis. Nature. 2002; 417(6886): 254-9.

[62] Kyle RA, Linos A, Beard CM, Linke RP, Gertz MA, O'Fallon WM, Kurland LT. Incidence and natural history of primary systemic amyloidosis in Olmsted County, Minnesota, 1950 through 1989. Blood. 1992; 79(7): 1817-22.

[63] Falk RH, Comenzo RL, Skinner M. The systemic amyloidoses. N Engl J Med. 1997; 337(13): 898-909.

[64] Gillmore JD, Hawkins PN, Pepys MB. Amyloidosis: a review of recent diagnostic and therapeutic developments. Br J Haematol. 1997; 99(2): 245-56.

[65] Nasr SH, Said SM, Valeri AM, Sethi S, Fidler ME, Cornell LD, Gertz MA, Dispenzieri A, Buadi FK, Vrana JA, Theis JD, Dogan A, Leung N. The diagnosis and characteristics of renal heavy-chain and heavy/light-chain amyloidosis and their comparison with renal light-chain amyloidosis. Kidney Int. 2013; 83(3): 463-70. 
[66] Said SM, Sethi S, Valeri AM, Chang A, Nast CC, Krahl L,Molloy P, Barry M, Fidler ME, Cornell LD, Leung N, Vrana JA, Theis JD, Dogan A, Nasr SH. Characterization and outcomes of renal leukocyte chemotactic factor 2-associated amyloidosis. Kidney Int. 2014; 86(2): 370-7.

[67] Sattianayagam PT, Gibbs SD, Pinney JH, Wechalekar AD, Lachmann HJ, Whelan CJ, Gilbertson JA, Hawkins PN, Gillmore JD. Solid organ transplantation in AL amyloidosis. Am J Transplant. 2010; 10(9): 2124-31.

[68] Herrmann SM, Gertz MA, Stegall MD, Dispenzieri A, Cosio FC, Kumar S, Lacy MQ, Dean PG, Prieto M, Zeldenrust SR, Buadi FK, Russell SJ, Nyberg SL, Hayman SR, Dingli D, Fervenza FC, Leung N. Long-term outcomes of patients with light chain amyloidosis (AL) after renal transplantation with or without stem cell transplantation. Nephrol Dial Transplant. 2011; 26(6): 2032-6.

[69] Pinney JH, Lachmann HJ, Sattianayagam PT, Gibbs SD, Wechalekar AD, Venner CP, Whelan CJ, Gilbertson JA, Rowczenio D, Hawkins PN, Gillmore JD. Renal transplantation in systemic amyloidosis-importance of amyloid fibril type and precursor protein abundance. Am J Transplant. 2013; 13(2): 433-41.

[70] Kofman T, Grimbert P, Canouï-Poitrine F, Zuber J, Garrigue V, Mousson C, Frimat L, Kamar N, Couvrat G, Bouvier N, Albano L, Le Thuaut A, Pillebout E, Choukroun G, Couzi L, Peltier J, Mariat C, Delahousse M, Buchler M, Le Pogamp P, Bridoux F, PouteilNoble C, Lang P, Audard V. Renal transplantation in patients with AA amyloidosis nephropathy: results from a French multicenter study. Am J Transplant. 2011; 11(11): 2423-31. 
